\title{
Carbon and nitrogen isotopic compositions of particulate organic matter and biogeochemical processes in the eutrophic Danshuei Estuary in northern Taiwan
}

\author{
Kon-Kee Liu ${ }^{\text {a,b,* }}$, Shuh-Ji Kao ${ }^{\text {c }}$, Liang-Saw Wen ${ }^{d}$, Kuan-Lun Chen ${ }^{\text {d }}$ \\ a Institute of Hydrological Sciences, National Central University, Taiwan, Republic of China \\ b National Center for Ocean Research, Taiwan, Republic of China \\ ${ }^{\mathrm{c}}$ Research Center for Environmental Changes, Academia Sinica, Taiwan, Republic of China \\ ${ }^{\mathrm{d}}$ Institute of Oceanography, National Taiwan University, Taiwan, Republic of China
}

Received 30 August 2006; received in revised form 16 April 2007; accepted 17 April 2007

Available online 23 May 2007

\begin{abstract}
The Danshuei Estuary is distinctive for the relatively short residence time $(1-2 \mathrm{~d})$ of its estuarine water and the very high concentration of ammonia, which is the dominant species of dissolved inorganic nitrogen in the estuary, except near the river mouth. These characteristics make the dynamics of nitrogen cycling distinctively different from previously studied estuaries and result in unusual isotopic compositions of particulate nitrogen (PN). The $\delta^{15} \mathrm{~N}_{\mathrm{PN}}$ values ranging from $-16.4 \%$ o to $3.8 \%$ o lie in the lower end of nitrogen isotopic compositions $(-16.4$ to $+18.7 \%$ ) of suspended particulate matter observed in estuaries, while the $\delta^{13} \mathrm{C}$ values of particulate organic carbon (POC) and the $\mathrm{C} / \mathrm{N}$ (organic carbon to nitrogen) ratios showed rather normal ranges from $-25.5 \%$ o to $-19.0 \%$ and from 6.0 to 11.3 , respectively. There were three major types of particulate organic matter (POM) in the estuary: natural terrigenous materials consisting mainly of soils and bedrock-derived sediments, anthropogenic wastes and autochthonous materials from the aquatic system. During the typhoon induced flood period in August 2000, the flux-weighted mean of $\delta^{13} \mathrm{C}_{\mathrm{POC}}$ values was $-24.4 \%$, that of $\delta^{15} \mathrm{~N}_{\mathrm{PN}}$ values was $+2.3 \%$ and that of $\mathrm{C} / \mathrm{N}$ ratio was 9.3 . During non-typhoon periods, the concentration-weighted mean was $-23.6 \%$ for $\delta{ }^{13} \mathrm{C}_{\mathrm{POC}},-2.6 \%$ for $\delta{ }^{15} \mathrm{~N}_{\mathrm{PN}}$ and 8.0 for $\mathrm{C} / \mathrm{N}$ ratio. From the distribution of $\delta^{15} \mathrm{~N}_{\mathrm{PN}}$ values of highly polluted estuarine waters, we identified the waste-dominated samples and calculated their mean properties: $\delta^{13} \mathrm{C}_{\mathrm{POC}}$ value of $-23.6 \pm 0.7 \%$, $\delta{ }^{15} \mathrm{~N}_{\mathrm{PN}}$ value of $-3.0 \pm 0.1 \%$ and $\mathrm{C} / \mathrm{N}$ ratio of $8.0 \pm 1.4$. Using a three endmember mixing model based on $\delta^{15} \mathrm{~N}_{\mathrm{PN}}$ values and $\mathrm{C} / \mathrm{N}$ ratios, we calculated contributions of the three major allochthonous sources of POC, namely, wastes, soils and bedrock-derived sediments, to the estuary. Their contributions were, respectively, $83 \%$, $12 \%$ and $5 \%$ under non-typhoon conditions, and $9 \%, 63 \%$ and $28 \%$ under typhoon conditions. The autochthonous POM had the most varied isotopic compositions, encompassing the full ranges of $\delta^{13} \mathrm{C}_{\mathrm{POC}}(-25.5$ to $-19.1 \% \mathrm{o}), \delta^{15} \mathrm{~N}_{\mathrm{PN}}(-16.4-3.8 \%$ and $\mathrm{C} / \mathrm{N}$ ratio (6.0-11.3). The heavy end of the carbon isotopic composition reflected the typical marine condition and the lower end the estuarine condition, which probably had elevated concentrations of dissolved inorganic carbon with low $\delta^{13} \mathrm{C}$ values due to input from decomposition of organic matter. The lack of isotopically heavy PN, as found in larger estuaries, was attributed to isotopically light starting materials, namely, anthropogenic wastes, the slow phytoplankton growth within the estuary and the rather short residence time; the latter two factors made ${ }^{15} \mathrm{~N}$ enrichment during ammonia consumption very limited. The most isotopically light
\end{abstract}

\footnotetext{
* Corresponding author. Institute of Hydrological Sciences, National Central University, Jungli, Taoyuan, 32001, Taiwan, Republic of China. Tel.: +8863422 3354; fax: +8863422 2894 .

E-mail address: kkliu@ncu.edu.tw (K.-K. Liu).
} 
PN likely originated from phytoplankton incorporating ${ }^{15} \mathrm{~N}$-depleted nitrate near the river mouth, where ammonia inhibition of nitrate uptake probably stopped.

(C) 2007 Elsevier B.V. All rights reserved.

Keywords: Particulate organic matter; Estuary; Carbon; Nitrogen; Isotopes; Eutrophic; Taiwan

\section{Introduction}

The Danshuei River (Fig. 1), also known as the Tamshui River, is the largest river in northern Taiwan, where the population density ( 2380 persons $\mathrm{km}^{-2}$ ) is the highest in Taiwan. The high population brings a heavy loading of anthropogenic wastes to the river. Until 1990, a large fraction of sewage and surface runoff was discharged into the river with no or primitive treatment due to the inadequate sewer system. Although a sewage treatment plant with a planned capacity of $1.32 \mathrm{Mt} \mathrm{d}^{-1}$ was built in the $1990 \mathrm{~s}$, its operation never reached its goal because of flawed design and engineering problems (Lo, 2001). Consequently, the Danshuei Estuary is highly eutrophied and polluted (Wen et al., 2007). At some monitoring stations, the mean concentration of dissolved oxygen in surface water dropped to $97 \mu \mathrm{M}$, and mean total organic carbon loading rose to $500 \mu \mathrm{M}$, mean total nitrogen loading to $570 \mu \mathrm{M}$, and mean concentration of total dissolved copper to $60 \mathrm{mgL}^{-1}$ (Sun and Peng, 2001).

The purpose of this study was to trace the origin of particulate organic matter (POM) in the Danshuei Estuary. POM is especially important in the estuarine system because of its capacity to carry trace metals and hydrophobic organic pollutants (Santschi et al., 1997; Ko and Baker, 2004), its high oxygen demand and its potential to release nutrient elements upon degradation. Carbon and nitrogen isotopes have long been used as indicators of different sources of organic matter in aquatic environments (Peters et al., 1978; Wada et al., 1987; Cifuentes et al., 1988; Kao and Liu, 2000; Sigleo and Macko, 2002). The combination of these isotopic signatures or the dual isotope composition has proven useful in differentiating the origins of POM in estuarine and coastal environments (Rau et al., 1981; Cifuentes et al., 1988; McClelland and Valiela, 1998). For this study, we try to understand the

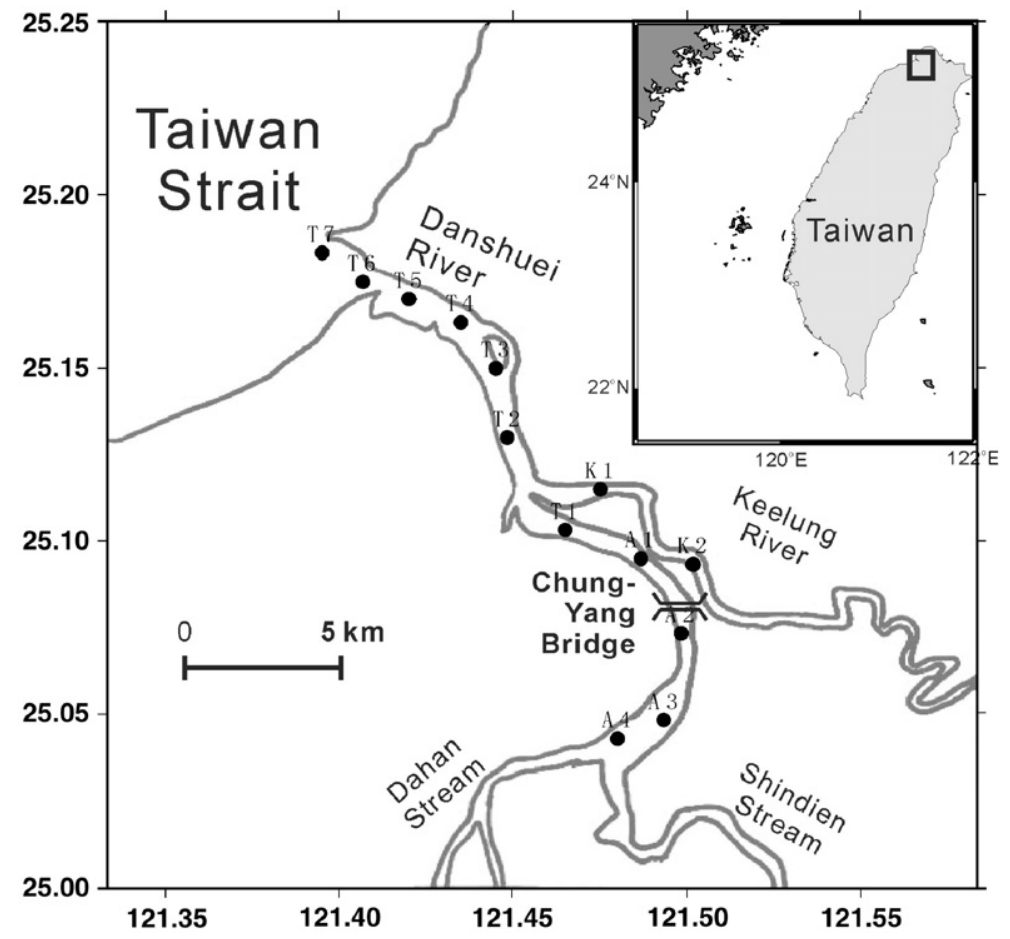

Fig. 1. Locations of sampling sites in the Danshuei Estuary, northern Taiwan. 
biogeochemical processes that control the isotopic compositions and distinguish the highly polluted Danshuei Estuary from others. We also attempt to determine the contributions from major external sources of POM to the estuary using carbon and nitrogen isotopic compositions and geochemical characteristics.

\section{Materials and methods}

\subsection{Sampling and area description}

Samples were collected from the Danshuei Estuary (Fig. 1) on five occasions between August 2000 and March 2001 (Table 1) covering a wide range of flow conditions, from nearly base flow (March 2001) to flooding (August 2000). For the latter, water samples were collected during and after the invasion of Typhoon Bilis at the Chung-Yang Bridge (Fig. 1). A bucket was lowered from the bridge to collect the water sample 2-5 times every day during the period from 22 August to 24 August and once per day from 28-30 August. On other occasions (Wen et al., 2007), water samples were collected (Fig. 1) on board a small boat cruising in the Danshuei Estuary. Samples were collected using a peristaltic pump system equipped with Teflon tubing inlets and outlets. For sample collection, the tubing was attached to a nonmetallic pole and the tubing inlet oriented into the current at about $0.25 \mathrm{~m}$ depth. Prior to sample collection, the sampling system was flushed for 5 to $10 \mathrm{~min}$ at a flow rate of approximately $300 \mathrm{ml} / \mathrm{min}$ to remove any possible residuals in the tubing. Water column properties were measured with a multi-sensor CTD unit (Hydrolab DataSonde 911). The collected samples were stored in ice chests and returned to the laboratory prior to analysis. Two samples of sewage sludge were collected from the Dihua Waste Water Treatment Plant of Taipei City.

The Danshuei River has three major tributaries, the Dahan Stream, the Shindien Stream and the Keelung River (Fig. 1). The area of the drainage basin is $2,726 \mathrm{~km}^{2}$, about $7.6 \%$ of the total area of Taiwan. The primary soils are Entisol and Inceptisol according to Soil Taxonomy (Soil-Survey-Staff, 1999). The underlying geology is dominated by argillite and slate with sandstone interbeds formed after the Oligocene (Ho, 1975). Montane forest covers about $93 \%$ of the watershed land area, agricultural land use comprises $5 \%$ and $<1 \%$ belongs to residential areas and other man-made constructions, including roads.

The length of the main stem is $159 \mathrm{~km}$. The mean annual discharge is $210 \mathrm{~m}^{3} \mathrm{~s}^{-1}$. The headlands of the watershed reach a maximum altitude of $3529 \mathrm{~m}$. The area with altitude less than 250 m comprises approximately $1 /$ 3 of the total area; the flat area with altitude less than $20 \mathrm{~m}$ in the Taipei basin is only $243 \mathrm{~km}^{2}$. The length of the tidal excursion along the main channel is about $30 \mathrm{~km}$ with a mean tidal range of $2.2 \mathrm{~m}$ (Liu et al., 2001). The depth in the lower reach (10 km from the river mouth) of the Danshuei Estuary varies mostly between 4 and $8 \mathrm{~m}$. Due to the shallowness of the estuary, it is well mixed in most areas with the exception for a short section near Station T2 (Fig. 1), where the channel depth reaches $12 \mathrm{~m}$ and two layer circulation occurs (Wang et al., 2004). The residence time of the estuarine water was estimated to be only $1-2 \mathrm{~d}$ under the mean flow, while the fresh water flush time is about twice this value (Wang et al., 2004). The total population within the drainage basin is about 6.5 million, but the distribution is very uneven due to the hilly topography. The most densely populated region has a population density as high as $9684 \mathrm{~km}^{-2}$ in the Taipei Metropolitan area around the Danshuei Estuary. The mean temperature of the estuary water varies between $12{ }^{\circ} \mathrm{C}$ in winter and $30{ }^{\circ} \mathrm{C}$ in summer (http://wqshow.epa.gov.tw/). Diatoms are usually the most abundant taxonomic group in the entire Danshuei Estuary in every season, whereas the abundance of chlorophytes and cyanobacteria increases towards the upriver region (Wu and Chou, 2003).

\subsection{Chemical analyses}

Suspended particulate matter (SPM) was obtained by filtering 0.5 to $2 \mathrm{~L}$ of water through a Whatman ${ }^{\circledR}$ quartz filter, $47 \mathrm{~mm}$ in diameter with mean pore size of $2 \mu \mathrm{M}$, for each sample shortly after collection. The quartz filters were preheated at $500{ }^{\circ} \mathrm{C}$ in an oven for the removal of organic matter and wrapped in aluminum foil before use. After filtration, the filters were folded and wrapped again

Table 1

Sampling records

\begin{tabular}{llll}
\hline Date & Sites & No. of samples & Note \\
\hline $22-24$ Aug. 2000 & Chung-Yang Bridge & 12 & Typhoon, 2-5 times per day \\
$28-30$ Aug. 2000 & Chung-Yang Bridge & 3 & Post-typhoon, daily \\
23 Sept. 2000 & Along estuary & 9 & 8 during flood tide, 8 during ebb \\
11 Dec. 2000 & Along estuary & 16 & 11 during flood tide, 11 during ebb \\
17 Mar. 2001 & Along estuary & 22 & \\
\hline
\end{tabular}


Table 2

Summary of $\delta^{13} \mathrm{C}_{\mathrm{POC}}$ and $\delta^{15} \mathrm{~N}_{\mathrm{PN}}$ values and $\mathrm{C} / \mathrm{N}$ ratios observed in the Danshuei Estuary

\begin{tabular}{|c|c|c|c|c|c|}
\hline Localities & Types & $\delta^{13} \mathrm{C}_{\mathrm{POC}}(\%)$ & $\delta^{15} \mathrm{~N}_{\mathrm{PN}}(\% 0)$ & $\mathrm{C} / \mathrm{N}$ & Data sources \\
\hline \multicolumn{6}{|l|}{ Danshuei river } \\
\hline (Non-typhoon) & Estuarine SPM & -25.5 to $-19.0(-23.1)$ & -16.4 to $3.8(-2.6)$ & $6.0-11.3(8.0)$ & 1 \\
\hline (Typhoon) & Estuarine SPM & -24.9 to $-23.8(-24.4)$ & $-2.7-3.0(2.3)$ & $5.6-11.3(9.3)$ & 2 \\
\hline Forth Estuary, Scotland & Estuarine sediments & -24.4 to -23.6 & $4.7-6.2$ & $10-42$ & 3 \\
\hline \multirow[t]{4}{*}{ Schelde Estuary } & Terrestrial end-member & -26.0 & 3.5 & 21.0 & 4 \\
\hline & Riverine end-member & -30.0 & 9.0 & 7.5 & 4 \\
\hline & Estuarine end-member & -29.0 & 15.0 & 8 & 4 \\
\hline & Marine end-member & -18.0 & 9.0 & 8.0 & 4 \\
\hline Tokachi River, Japan & Estuarine SPM & -28.8 to -25.2 & $0.4-4.0$ & $6.0-12.2$ & 5 \\
\hline Delaware Estuary, USA & Estuarine SPM & -25.8 to -16.4 & $3.7-18.7$ & $5-18$ & 6 \\
\hline Potomac River, USA & Estuarine SPM & -27.5 to -18.4 & $3.1-12.6$ & $7-12$ & 7 \\
\hline Brantas River, Java, Indonesia & Estuarine SPM & -28.9 to -19.6 & $-2.3-10$ & $6.4-12.7$ & 8 \\
\hline
\end{tabular}

Values in the parentheses are averages weighted by concentration under non-typhoon conditions or by flux under typhoon conditions. Observations from six other estuaries are also listed for comparison. $\mathrm{C} / \mathrm{N}$ is the atomic ratio.

1. This study. 2. Chen et al. (2001). 3. Middelburg and Nieuwenhuize (1998). 4. Graham et al. (2001). 5. Usui et al. (2006). 6. Cifuentes et al. (1988).

7. Sigleo and Macko (2002). 8. Jennerjahn et al. (2004).

in aluminum foil and stored in a freezer until analysis. The filtrate was stored in $100 \mathrm{~mL}$ polypropylene sample bottles, which were kept in an ice chest for chemical analyses performed immediately after sampling except those collected in August 2000; on that occasion, the filtrates were frozen in liquid nitrogen for later analyses.

Nutrients, including nitrate, nitrite, ammonia, phosphate and silicate were analyzed in the shore-based laboratory at the National Center for Ocean Research. Frozen samples were thawed under tap water. Nitrate and nitrite were analyzed by the standard pink azo dye method adapted for flow injection analyzer (Pai et al., 1990b); ammonium by an improved indophenol blue method (Pai et al., 2001); phosphate and silicate by the standard molybdenum blue method with a flow injection analyzer (Pai et al., 1990a). The precision of the analyses was $\pm 0.3 \mu \mathrm{M}$ for nitrate and nitrite, $\pm 0.5 \mu \mathrm{M}$ for ammonia, $\pm 0.05 \mu \mathrm{M}$ for phosphate and $\pm 0.5 \mu \mathrm{M}$ for silicate. It is noted that ammonia was analyzed only on samples collected in December 2000 and March 2001.

Chl-a samples were obtained by filtering two liters of waters through $\mathrm{GF} / \mathrm{F}$ filters (Whatman ${ }^{\circledR}, 47 \mathrm{~mm}$ ) and stored at $-20^{\circ} \mathrm{C}$. The phytoplankton pigments retained on GF/F filters were extracted in 90\% acetone (Strickland and Parsons, 1972). The Chl-a concentrations in the extracts were measured with a fluorometer (Turner 10-AU-005).

\subsection{Isotopic analyses}

The filters bearing SPM were dried at $70{ }^{\circ} \mathrm{C}$ in an oven, and then acidified with $1 \mathrm{ml}$ of $1 \mathrm{~N}$ solution of reagent grade $\mathrm{HCl}$ for the removal of carbonate. The sewage sludge samples were freeze-dried. About $0.2 \mathrm{~g}$ of the freeze-dried samples was treated with $15 \mathrm{ml} 1 \mathrm{~N}$
$\mathrm{HCl}$ for $2 \mathrm{~d}$ in pre-combusted $\left(500{ }^{\circ} \mathrm{C}\right)$ glass test-tubes and then centrifuged for removal of solution. The acidtreated samples were dried at $60^{\circ} \mathrm{C}$ in an oven for $48 \mathrm{~h}$. The dried samples were processed for the preparation of carbon and nitrogen isotope samples by means of the sealed tube combustion method (Wedeking et al., 1983), followed by gas purification for mass spectrometric analysis. Because inorganic carbon is effectively removed from the solid samples in the pretreatment, the carbon analyzed is referred to as particulate organic carbon (POC) in this study. By contrast, the inorganic nitrogen that may exist in mineral phases of the SPM, albeit in minute amounts, cannot be effectively removed; therefore, the nitrogen analyzed is referred to as particulate nitrogen $(\mathrm{PN})$ in this study.

Each of the decarbonated samples was mixed with $1 \mathrm{~g}$ each of $\mathrm{CuO}$ and $\mathrm{Cu}$ pellets and several inches of silver wire, and then sealed in an evacuated 9-mm quartz tube. Sealed quartz tubes were then heated at $900{ }^{\circ} \mathrm{C}$ for $3 \mathrm{~h}$, kept at $650{ }^{\circ} \mathrm{C}$ for over $12 \mathrm{~h}$, and cooled to room temperature. $\mathrm{N}_{2}$ and $\mathrm{CO}_{2}$ gases were extracted and purified by cryogenic traps in a vacuum line and collected in sealed 6-mm glass tubes. The abundances of carbon and nitrogen were measured manometrically in the vacuum line. This method had been crosschecked previously by Leco ${ }^{\circledR}$ Carbon Analyzer and gave consistent results with a relative standard deviation less than 5\% (Chang et al., 1991). Carbon and nitrogen isotopic compositions were determined in a Micromass VG602E mass spectrometer. Results are presented in the standard $\delta$ notation with respect to standards of atmospheric nitrogen and Peedee Belemnite (PDB) carbon for $\delta{ }^{15} \mathrm{~N}$ and $\delta{ }^{13} \mathrm{C}$, respectively. The precision of nitrogen and carbon isotopic determination was better 
than $\pm 0.2 \%$ as determined from repeated measurements of a working standard, the reagent grade histidine.

\section{Results}

All sampling stations are within the tidal reach of the estuary. During the sampling occasions, except the typhoon period in August 2000, the salinity front with $50 \%$ seawater in the surface water fluctuated between Station T5 at ebb tide and Station T1 at flood tide (Fig. 1). The mean water temperature was $22.3 \pm 0.5{ }^{\circ} \mathrm{C}$ in September 2000, 19.9 $\pm 1.0^{\circ} \mathrm{C}$ in December 2000 and
$20.2 \pm 0.7^{\circ} \mathrm{C}$ in March 2001 (http://wqshow.epa.gov.tw/). We first report results obtained on non-typhoon occasions as the "normal" condition, and then report those obtained under typhoon and post-typhoon conditions, which have been partially covered by Chen et al. (2001). The $\delta^{13} \mathrm{C}_{\mathrm{POC}}$ and $\delta^{15} \mathrm{~N}_{\mathrm{PN}}$ values and $\mathrm{C} / \mathrm{N}$ (organic carbon to nitrogen) ratios of SPM are summarized in Table 2.

\subsection{Non-typhoon conditions}

In order to focus on the biogeochemical processes controlling nutrient dynamics and isotopic compositions,

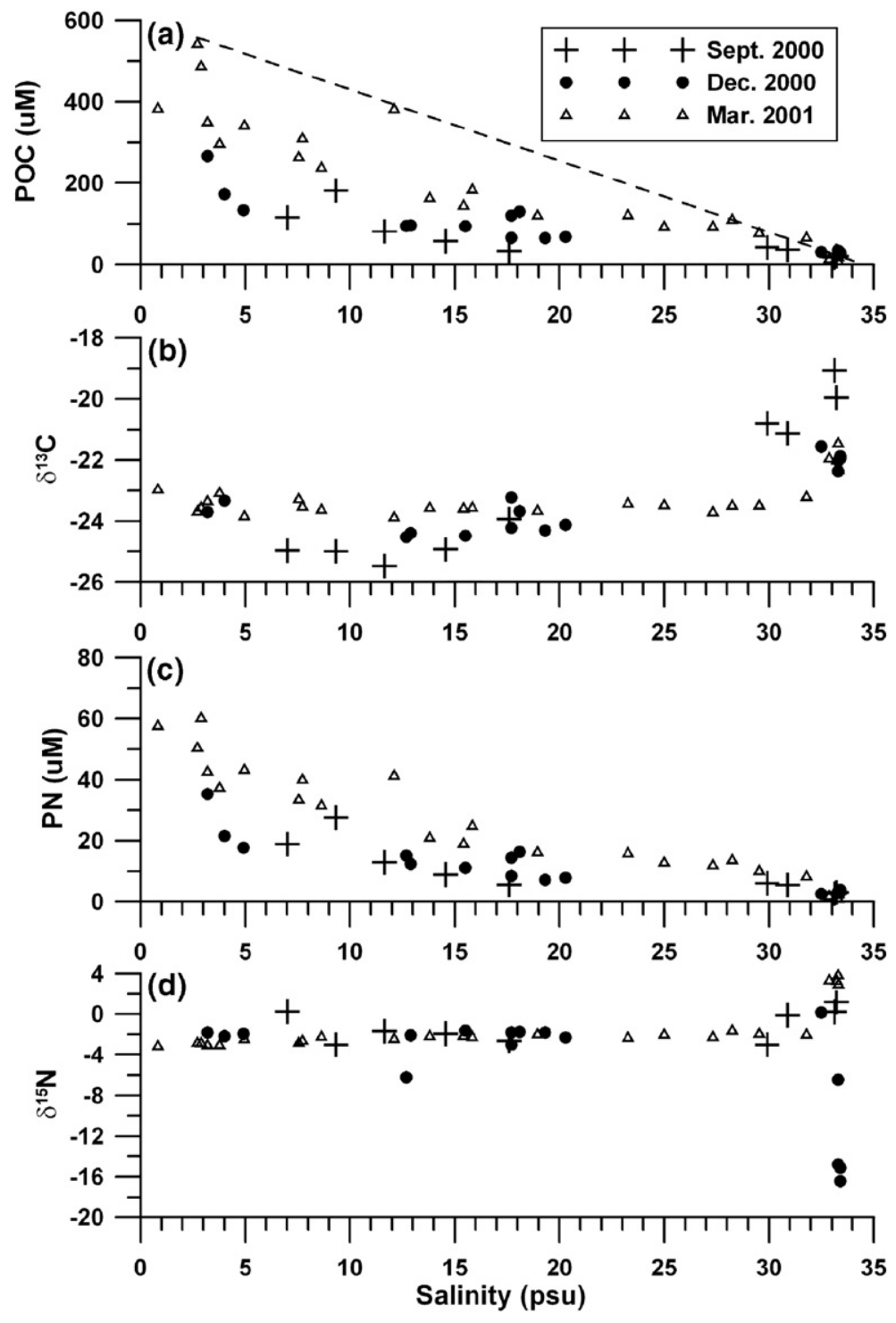

Fig. 2. Properties of suspended particulate matter vs. salinity observed on the three non-typhoon occasions in the Danshuei Estuary. The dashed line is the conservative mixing line for POC in March 2001. (a) For POC concentrations. (b) For $\delta^{13} C_{\mathrm{POC}}$ values. (c) Same as Fig. $2 \mathrm{a}$ except for PN concentrations. (d) Same as Fig. 2b except for $\delta^{15} \mathrm{~N}_{\mathrm{PN}}$ values. 
we report the results of our measurements versus salinity rather than describing the complicated spatial and temporal variations. The POC concentration decreased gradually with increasing salinity towards the river mouth from the peak values around $266-540 \mu \mathrm{M}$ at the uppermost stations (Fig. 2a). It is obvious that most POC data points fall significantly below the mixing curve, suggesting removal of POC within the estuary. In contrast to the nearly monotonous decrease of POC concentration with increasing salinity, its carbon isotopic composition (Fig. 2b) remained fairly constant with most $\delta^{13} \mathrm{C}_{\mathrm{POC}}$ value within a narrow range of -25 to $-23 \%$ before salinity reaching 30 ; beyond that, the $\delta^{13} \mathrm{C}_{\mathrm{POC}}$ increased abruptly reaching values as high as $-19 \%$. The variation of $\mathrm{PN}$ concentration (Fig. 2c) was quite similar to that of POC concentration with the highest value around $60 \mu \mathrm{M}$, and its isotopic composition (Fig. 2d) also remained invariant, mostly between $\delta^{15} \mathrm{~N}_{\mathrm{PN}}$ values of -4 and $-2 \%$, for salinity below 30 . Rather than showing an abrupt increase like $\delta{ }^{13} \mathrm{C}$ values of POC for salinity above 30 , the $\delta^{15} \mathrm{~N}_{\mathrm{PN}}$ value diverged in both directions. The sewage sludge samples displayed $\delta{ }^{13} \mathrm{C}_{\mathrm{POC}}$ and $\delta{ }^{15} \mathrm{~N}_{\mathrm{PN}}$ ranges of -24.9 to $-24.7 \%$ and $2-3 \%$, respectively, well within the isotopic composition ranges of the SPM.

Contrary to the rather similar distribution patterns of POC and PN observed on different sampling occasions,

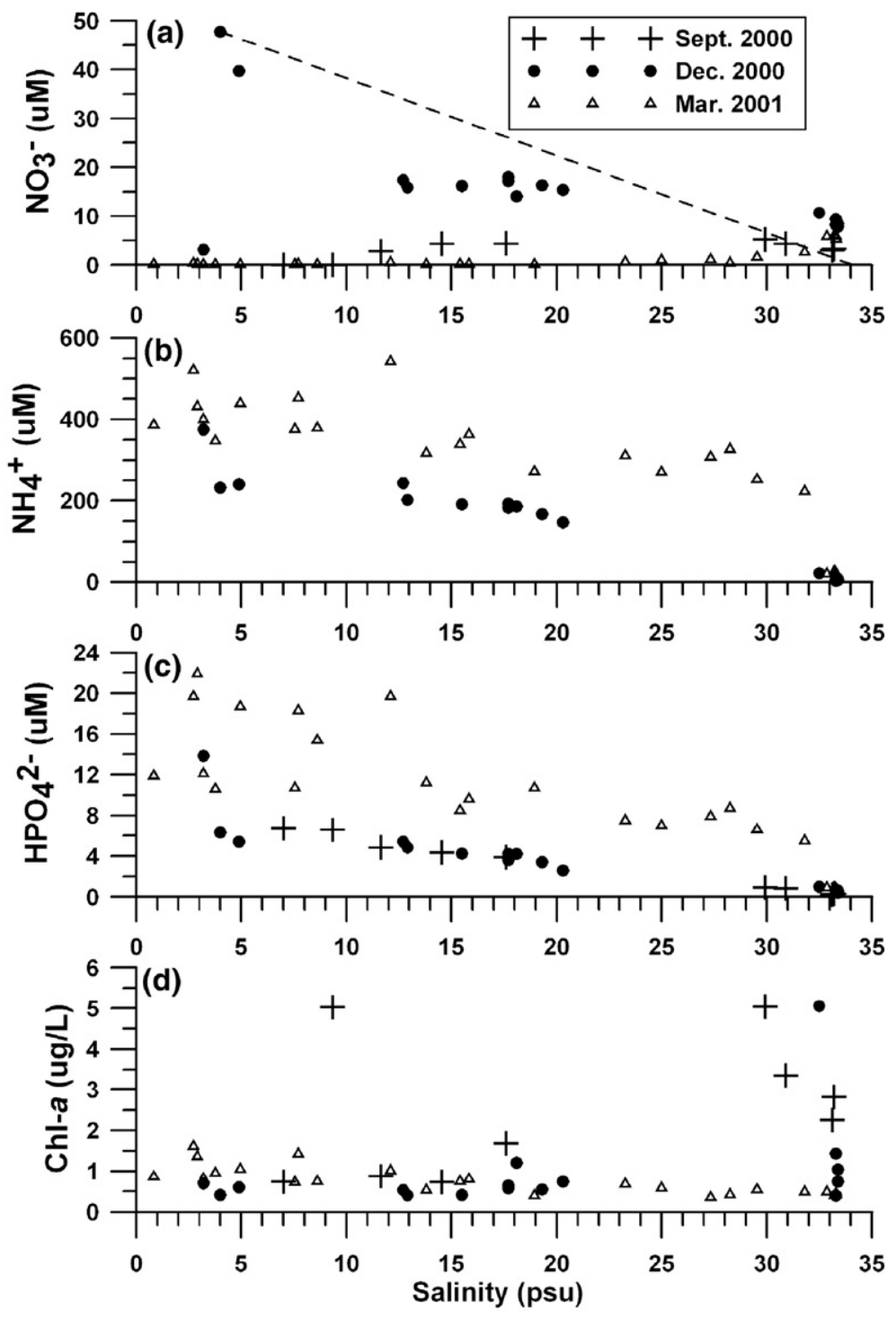

Fig. 3. Same as Fig. 2 except for nutrients and Chl-a concentrations. The dashed line is the conservative mixing line for nitrate in December 2000. (a) Nitrate. (b) Ammonia. (c) Phosphate. (d) Chl-a. It is noted that ammonia was not analyzed on the samples collected in September 2000. 
the variation of different species of dissolved inorganic nitrogen across the salinity gradient changed drastically on different occasions (Fig. 3). In most cases ammonia was the dominant species of dissolved inorganic nitrogen (DIN) with an observed maximum concentration of $542 \mu \mathrm{M}$ (Fig. 3b). Nitrate was usually the second most abundant species of DIN (Fig. 3a), but nitrite concentrations (not shown) exceeded those of nitrate for salinity lower than 18 in September 2000. It is noted that nitrate concentrations in December 2000 were much higher than those observed on the other two occasions (Fig. 3a), but the sample with the lowest salinity had a rather low nitrate concentration, resembling those from the other two occasions. The abrupt change in nitrate concentration suggests multiple sources of nutrients to the estuary, which are worth of exploring. A mixing line (Fig. 3a) is drawn to depict the conservative mixing between the nitrate-rich estuarine water and the coastal surface seawater with a salinity of 34 and nearly no nitrate (Gong et al., 1995). Nitrate deficit in the mid salinity waters indicates removal of nitrate, but nitrate excess in the high salinity waters suggests nitrification occurring near the river mouth. Slight increases of nitrate in the high salinity waters occurred in September 2000 and March 2001 (Fig. 3a), also indicating occurrences of nitrification.

The phosphate concentration (Fig. 3c) showed a similar distribution pattern as that of ammonia. The Chla concentration (Fig. 3d) stayed at relatively low values of less than $2 \mu \mathrm{g} / \mathrm{L}$ for all samples with salinity less than 30 except one. The low Chl-a concentrations in the presence of so much nutrients suggest that the short residence time of the estuarine water did not allow the phytoplankton to grow before they were flushed out of the estuary. A similar situation also occurs in the fast flushed Tweed Estuary, England (Uncles et al., 2000). Near the river mouth Chl-a increased abruptly up to $5 \mu \mathrm{g} / \mathrm{L}$ for salinity above 30 , resembling the increases of $\delta^{13} \mathrm{C}_{\mathrm{POC}}$ values. The concurrence of the changes suggests that the ${ }^{13} \mathrm{C}$-enriched $\mathrm{POC}$ and the significant Chl-a increments near the river mouth are closely related. This is to be discussed later. It is worth noting that most of the higher Chl-a concentrations were observed in September 2000, the first sampling occasion after the typhoon flood, suggesting the relatively fresh conditions favored phytoplankton growth.

\subsection{Typhoon and post-typhoon conditions}

Geochemical variations of the river water under typhoon and post-typhoon conditions have been described in detail (Chen et al., 2001) and are only briefly presented here. The peak concentrations of POC $(4325 \mu \mathrm{M})$ and $\mathrm{PN}(420 \mu \mathrm{M})$ corresponded to the peak flow of $3000 \mathrm{~m}^{3} \mathrm{~s}^{-1}$. The positive correlation (Chen et al., 2001) between discharge rate and POC concentration is indicated by the high $R^{2}$ value of 0.87 ; a similar correlation is evident for PN with $R^{2}$ value of 0.88 .

The carbon isotopic composition of POC fluctuated between $\delta^{13} \mathrm{C}$ values of $-25 \%$ and $-24 \%$ with no clear trend. By contrast, the $\delta^{15} \mathrm{~N}_{\mathrm{PN}}$ value increased sharply from $-2.5 \%$ to $+3 \%$ as $\mathrm{PN}$ concentration increased abruptly responding to the flood. When the flood subsided, the relatively high $\delta{ }^{15} \mathrm{~N}_{\mathrm{PN}}$ value persisted for $1 \mathrm{~d}$ and then dropped slightly to $+2 \%$ and remained nearly constant in the post-typhoon condition. Both POC and PN concentrations dropped dramatically after the peak flow, but stayed at levels of $400-1400 \mu \mathrm{M}$ for POC

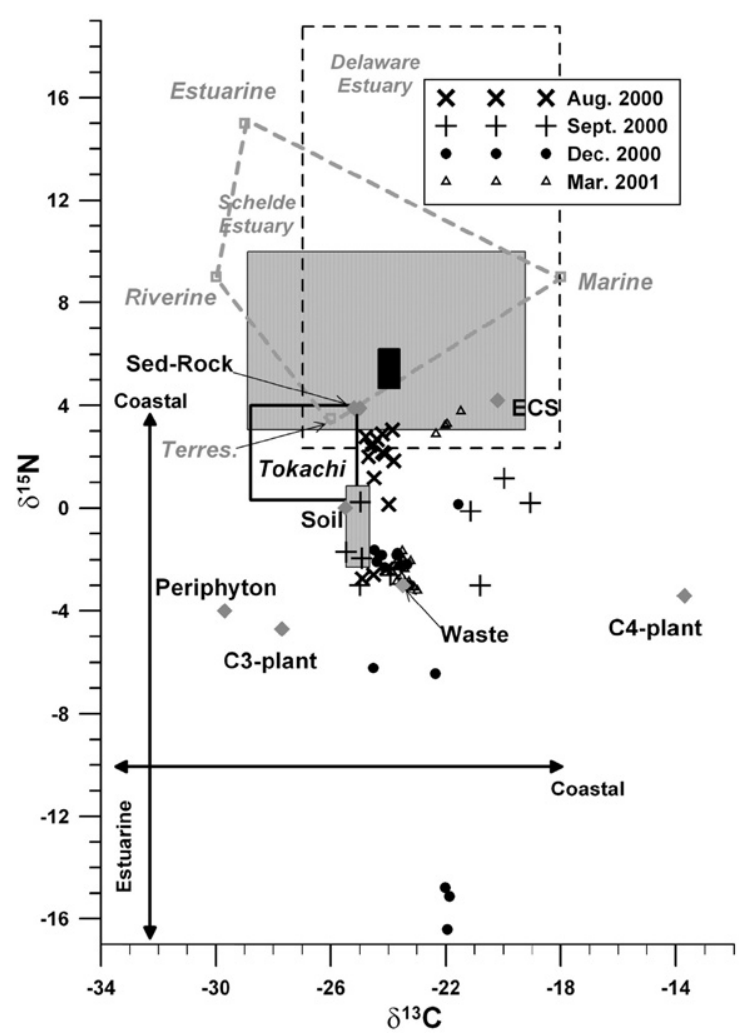

Fig. 4. Plot of $\delta^{15} \mathrm{~N}_{\mathrm{PN}}$ Vs. $\delta^{13} \mathrm{C}_{\mathrm{POC}}$ observed in the Danshuei Estuary. Also plotted are potential end-members (gray diamonds) of organic matter listed in Table 3. (ECS stands for East China Sea.) The two thick lines with arrows indicate the range of $\delta^{13} \mathrm{C}$ and $\delta^{15} \mathrm{~N}$ values that may be acquired by the newly produced POM in the estuary-coastal zone continuum. For comparison, observed ranges from other estuaries are plotted as the polygon and rectangles (Table 2). Three sites are labeled. The unlabeled are the Forth Estuary (solid black rectangle) and the Brantas River (shaded rectangles); the latter displayed two distinctive areas of data distribution (see text). The open squares at the corners of the dashed polygon represent the four end-members found for the Schelde Estuary. 
Table 3

Carbon and nitrogen isotopic and elemental compositions of potential sources of POM in the Danshuei Estuary

\begin{tabular}{|c|c|c|c|c|c|}
\hline Localities & Sample types & $\delta^{13} \mathrm{C}_{\mathrm{POC}}(\% \mathrm{o})$ & $\delta^{15} \mathrm{~N}_{\mathrm{PN}}(\%)$ & $\mathrm{C} / \mathrm{N}$ & Data sources \\
\hline Northern Taiwan & Terrestrial plants (C3) & $-27.7 \pm 1.7$ & $-4.7 \pm 1.2$ & $35.3 \pm 8.9$ & 1 \\
\hline Northern Taiwan & Terrestrial plants (C4) & $-13.7 \pm 1.1$ & $-3.4 \pm 1.1$ & $36.6 \pm 0.6$ & 1 \\
\hline Northern Taiwan & Aquatic plants & $-29.7 \pm 2.5$ & $-3.97 \pm 0.4$ & $13.3 \pm 2.0$ & 1 \\
\hline Northern Taiwan & Bedrocks & $-25.0 \pm 0.2$ & $3.9 \pm 0.1$ & $5.8 \pm 0.5$ & 1 \\
\hline Northern Taiwan & River sediments & $-25.2 \pm 0.2$ & $3.9 \pm 0.1(3.9)$ & $5.8 \pm 0.5(6.2)$ & 1 \\
\hline Northern Taiwan & Soils & $-25.5 \pm 1.3$ & $-0.0 \pm 1.3(1.25)$ & $13.6 \pm 4.5(14.25)$ & 1 \\
\hline East China Sea & Marine SPM & $-20.2 \pm 1.5$ & $4.2 \pm 1.0$ & $8.0 \pm 0.3$ & 2 \\
\hline Danshuei River, Taiwan & Anthropogenic wastes & $-23.6 \pm 0.7$ & $-3.0 \pm 0.1(-3.0)$ & $8.0 \pm 1.4(7.5)$ & 3 \\
\hline Dihua Waste Water Treatment Plant, Taipei & Sludge & $-24.8 \pm 0.1$ & $2.5 \pm 0.7$ & & 3 \\
\hline Tay Estuary, Scotland & Sewage & -26.7 & 2.3 & 12.57 & 4 \\
\hline Deer Island, MA, USA & Effluent POM & & $1.1-3.3$ & & 5,6 \\
\hline Providence, RI, USA & Sludge & -23.7 & & & \\
\hline NY Bight, USA & Sludge & -26.0 & & & 7 \\
\hline Yonkers, NY, USA Sludge & Sludge & -21.4 & 7.2 & & 7 \\
\hline Middlesex, NJ, USA Sludge & Sludge & -24.7 & -1.1 & & 7 \\
\hline Bergen, NJ, USA Sludge & Sludge & -23.2 & 6.1 & & 7 \\
\hline Whites Point, Calif., USA & Sludge & -23.5 to -16.5 & 1.8 to 2.5 & & $8-10$ \\
\hline Hunts Bay, Jamaica & Sewage & $-24.8 \pm 3.2$ & & $12.5 \pm 1.0$ & 11 \\
\hline
\end{tabular}

The compositions of the end-members for the model calculation are shown in parentheses. Also listed are compositions of sewage-derived organics from nine other coastal areas. $\mathrm{C} / \mathrm{N}$ is the atomic ratio.

1. Kao and Liu (2000). 2. Chen et al. (2001). 3. This study. 4. Thornton and McManus (1994). 5. Tucker et al. (1999). 6. Hunt et al. (1995). 7. van Dover et al. (1992). 8. Meyers (1974). 9. Sweeney et al. (1980). 10. Spies et al. (1989). 11. Andrews et al. (1998).

and 75-140 for PN. These levels were generally higher than the normal range of $500 \mu \mathrm{M}$ or less for POC and $70 \mu \mathrm{M}$ or less for PN, while the discharge rate fluctuated between 500 and $1000 \mathrm{~m}^{3} / \mathrm{s}$ (Chen et al., 2001), which were 2-5 times above the mean level.

Using the hourly discharge rate recorded during the typhoon period, Chen et al. (2001) constructed rating curves for POC and PN as well as for carbon and nitrogen isotopes. The flux weighted mean of $\delta^{13} \mathrm{C}_{\mathrm{POC}}$ values was found to be $-24.4 \%$ and that of $\delta^{15} \mathrm{~N}_{\mathrm{PN}}$ values was $+2.3 \%$. The dual isotope composition fell between the mean compositions of soils and sediments (Fig. 4), suggesting these end-members to be the main sources of POC and PN during flood conditions. Since the sediments analyzed by Kao and Liu (2000) had the same mean isotopic composition as the bedrocks (Table 3), they are referred to as the bedrock-derived sediments.

\section{Discussion}

The origin of organic matter may be traced through geochemical characteristics, such as $\mathrm{C} / \mathrm{N}$ ratio and isotopic compositions (Table 2). Observations from other estuarine systems are shown for comparison (Table 2 and Fig. 4). The geochemical characteristics of potential end-members from the watershed-riverestuary system are shown in Table 3 as references. In addition to the known end-members, we discuss other possible sources of organic materials and the processes that may be responsible for the geochemical characteristics of these source materials.

\subsection{Geochemical characteristics}

Geochemical characteristics of POC and PN observed in the Danshuei Estuary are discussed for the purpose of delineating their origins.

\subsubsection{C/N ratio}

The POC and PN concentrations are highly correlated as observed throughout this study. Although the ranges of $\mathrm{C} / \mathrm{N}$ ratio observed in individual samples obtained during non-typhoon and typhoon periods are nearly identical (Table 2), the slopes of regression analyses differ considerably. Under non-typhoon conditions, the overall regression equation for concentration in units of $\mu \mathrm{M}$ is as follows:

$$
\begin{aligned}
\mathrm{PN} & =0.117 \pm 0.004 * \mathrm{POC}+1.4 \pm 0.7 \\
R^{2} & =0.96
\end{aligned}
$$

The $\mathrm{C} / \mathrm{N}$ ratio, which is the reciprocal of the slope, is $8.5 \pm 0.3$. For samples from typhoon and post-typhoon periods, the regression equation is

$$
\begin{aligned}
\mathrm{PN} & =0.0919 \pm 0.003 * \mathrm{POC}+15.9 \pm 5.2, \\
R^{2} & =0.988
\end{aligned}
$$




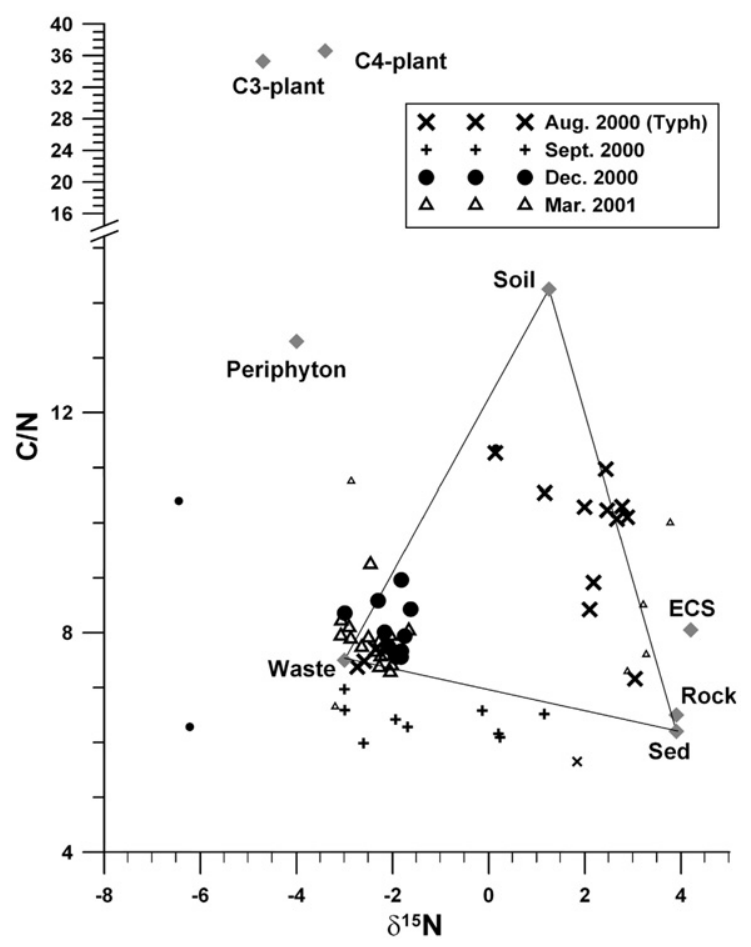

Fig. 5. Same as Fig. 5 except for $\mathrm{C} / \mathrm{N}$ ratio vs. $\delta^{15} \mathrm{~N}_{\mathrm{PN}}$ value. The triangle represents the field covered by the mixing of the three major allochthonous POM end-members, for which a 3 component mixing model was developed. The normal sized symbols represent the allochthonous POM dominated samples that allowed calculation of end-member contributions, while the smaller symbols, including all samples from September 2000, represent those, which did not allow the model calculation due to significant contribution of autochthonous POM or from other sources (see text). The horizontal axis does not cover the lowest part of the $\delta^{15} \mathrm{~N}_{\mathrm{PN}}$ range $(-16.4$ to $-8 \%$ ) occupied by only four samples.

The $\mathrm{C} / \mathrm{N}$ ratio corresponding to the slope is $10.9 \pm 0.3$. The difference suggests that the changes in POM concentration were attributed to different types of organic matter under typhoon and non-typhoon conditions.

During the typhoon period, the elevated POM concentration with higher $\mathrm{C} / \mathrm{N}$ ratio was probably attributed to additional input of soils, which had an average $\mathrm{C} / \mathrm{N}$ ratio of $13.6 \pm 4.5$ (Table 3 ), from the upstream catchment. The low $\mathrm{C} / \mathrm{N}$ ratios observed during non-typhoon periods resemble the aquatic end-members reported for the Schelde Estuary between the Netherlands and Belgium (Middelburg and Nieuwenhuize, 1998), but the isotopic signatures of POC and PN from the two estuaries are quite different (Table 2) and warrant further discussion to be given in following sections.

\subsubsection{Isotopic compositions}

The carbon and nitrogen isotopic compositions of POC and PN observed in the Danshuei Estuary are presented in the dual-isotope plot of $\delta^{13} \mathrm{C}$ vs. $\delta^{15} \mathrm{~N}$ (Fig. 4). The six types of organic source materials observed in the Lanyang Hsi watershed and the adjacent Fu-Shan Natural Preserve, which is located in one of the headlands of the Danshuei River watershed (Kao and Liu, 2000), are potential terrestrial sources. The POM obtained from the southern East China Sea (Chen et al., 2001) represents the potential marine end-member, which is to be discussed in Section 4.3.2. Their compositions are listed in Table 3 and plotted in Fig. 4.

The seven potential end-members cover almost the entire dual-isotope field occupied by the SPM samples of the Danshuei Estuary except the few samples with the unusually low $\delta{ }^{15} \mathrm{~N}_{\mathrm{PN}}$ values $(<-6 \%$ ), suggesting that these end-members could be significant in this study area. The dual isotope composition of POC-PN obtained during the typhoon and post-typhoon periods extended from the region of non-typhoon samples towards the compositions of soils and bedrock-derived sediments (Fig. 4). During and after the peak flow, the POC-PN compositions fell between soil and bedrock-derived sediments, suggesting that they are the primary sources of SPM during typhoon floods. This is consistent with previous findings (Kao and Liu, 2000).

However, the plot of $\mathrm{C} / \mathrm{N}$ ratio vs. $\delta^{15} \mathrm{~N}$ reveals quite a different picture (Fig. 5). It is difficult to account for the observed compositional variation in the $\mathrm{C} / \mathrm{N}-\delta^{15} \mathrm{~N}_{\mathrm{PN}}$ field in the Danshuei Estuary with the afore-mentioned endmembers. More than 2/3 of the data points fell out of the field defined by the potential end-members. Although the plants, including periphyton, may provide isotopically light organic nitrogen to the system, their $\mathrm{C} / \mathrm{N}$ ratios, $13-38$, are much higher than the estuarine POM. Hence, their contributions are probably not significant. An end-member with $\delta^{15} \mathrm{~N}_{\mathrm{PN}}$ value similar to the plants but lower $\mathrm{C} / \mathrm{N}$ ratio is required to account for the majority of the observations. The samples with unusually low $\delta^{15} \mathrm{~N}_{\mathrm{PN}}$ values, down to $-16.4 \%$, pose an even greater problem. The presence of

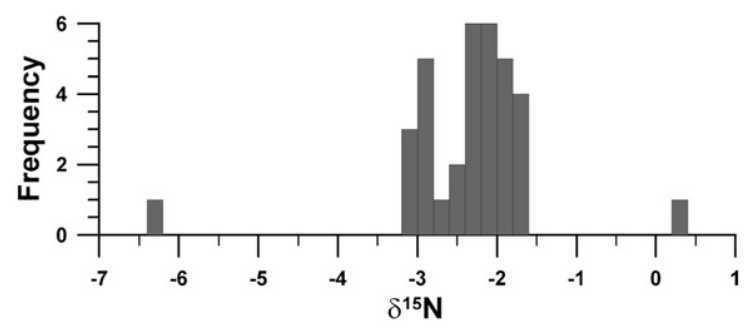

Fig. 6. Frequency of occurrences of $\delta^{15} \mathrm{~N}_{\mathrm{PN}}$ values among samples with phosphate concentration above $2.5 \mu \mathrm{M}$. The range of lowest $\delta^{15} \mathrm{~N}_{\mathrm{PN}}$ values with high occurring frequencies around $-3 \%$ is considered representative of anthropogenic wastes. (see text). 
the ${ }^{15} \mathrm{~N}$ depleted SPM in the Danshuei Estuary is worthy of attention.

\subsection{Comparison with other estuaries}

Observations from six other estuaries, ranging from the tropics (Brantas River, Java) to the cold temperate (Forth Estuary, Scotland), are included for the comparison (Table 2 and Fig. 4). In the Delaware Estuary, USA the isotopic compositions of $\mathrm{POM}$ cover the $\delta^{13} \mathrm{C}_{\mathrm{POC}}$ ranges of -26 to $-16.4 \%$ and the $\delta{ }^{15} \mathrm{~N}_{\mathrm{PN}}$ range of 2.3 to $18.7 \%$ (Cifuentes et al., 1988). Less than $1 / 6$ of the data points from the Danshuei Estuary fell within this domain (Fig. 4).

Middelburg and Nieuwenhuize (1998) proposed four end-members of organic source materials for the Schelde Estuary, including riverine and estuarine end-members in addition to the traditional terrestrial and marine endmembers (Peters et al., 1978). Aside from the terrestrial end-member, the isotopic compositions of other endmembers for the POM found in the Schelde Estuary are far from the observed dual-isotopic field in the Danshuei Estuary (Fig. 4). In fact, there is no overlapping between the dual isotope field defined by the four end-members of the Schelde Estuary and our observations.

Most $\delta^{13} \mathrm{C}_{\mathrm{POC}}$ and $\delta^{15} \mathrm{~N}_{\mathrm{PN}}$ values observed in other estuaries fall within the domains of the two aforementioned estuaries, which also show considerable overlapping. The observations in the Potomac River, USA (Sigleo and Macko, 2002) overlap considerably with the two, and, therefore, are not plotted for clarity of the figure. The only exceptions are data from the Tokachi River, Japan (Usui et al., 2006) and a few sites from the Brantas River, Java, Indonesia (Jennerjahn et al., 2004). The observed $\delta^{13} C_{\text {POC }}$ values from these sites lie in the low end of the full range and the $\delta^{15} \mathrm{~N}_{\mathrm{PN}}$ values are considerably lower than the majority, but similar to our observations.

At the Wonokromo Stations 1 II and 2 II of the Brantas River, the rather low $\delta^{15} \mathrm{~N}_{\mathrm{PN}}$ values $(-2.3-0.9 \%$ ) were attributed to nitrogen fixation performed by cyanobacteria, which were the dominant group of phytoplankton (Jennerjahn et al., 2004). However, the environmental conditions of these sites were characterized by low salinity $(0.3-2.4 \mathrm{psu})$, high nitrate $(98-118 \mu \mathrm{M})$ and low ammonium $(0.1-0.2 \mu \mathrm{M})$, which were very different from the conditions of the Danshuei Estuary. In addition, the low $\delta{ }^{15} \mathrm{~N}_{\mathrm{PN}}$ values occurred only at a few sites in the Brantas River, while such values occurred throughout the Danshuei Estuary. It seems unlikely that the same process was responsible for the very low values $\delta^{15} \mathrm{~N}_{\mathrm{PN}}$ observed in the Danshuei Estuary, because the very high ammonium concentration would inhibit nitrogen fixation. The relatively low $\delta^{15} \mathrm{~N}_{\mathrm{PN}}$ values observed in the Tokachi
River, Japan overlap considerably with those observed in the Danshuei Estuary, but no explanation was given by the authors (Usui et al., 2006).

\subsection{Organic source materials}

The foregoing discussion has illustrated that the geochemical characteristics of POC and PN in the Danshuei Estuary cannot be readily explained by the currently known natural sources of organic matter in northern Taiwan. Observations in other estuaries do not shed much light,either. Here we explore other possibilities.

\subsubsection{Anthropogenic wastes}

In the urbanized watershed, anthropogenic wastes are a major source of organic matter and nutrients (e.g., Sweeney et al., 1980; Tucker et al., 1999). In view of the very high concentration of dissolved inorganic nitrogen, especially in the Danshuei Estuary one expects anthropogenic wastes as a major end-member of POM. Nitrogen loading is a good indicator of anthropogenic wastes (Cole et al., 1993). Very good positive correlation is found between total loading of nitrogen and phosphate concentration in the Danshuei Estuary. For phosphate concentration above $2.5 \mu \mathrm{M}$, the total nitrogen concentration increased abruptly, suggesting a strong loading of anthropogenic waste-derived materials. Because ammonia was not analyzed for all samples but phosphate was, we use the phosphate concentration to indicate samples with severe pollution of anthropogenic wastes.

Analysis of occurrence frequencies of $\delta^{15} \mathrm{~N}_{\mathrm{PN}}$ values in water samples with phosphate above $2.5 \mu \mathrm{M}$ (Fig. 6) indicates that most values fell within the range of -3.2 to $-1.6 \%$ with a bimodal distribution. It is hypothesized that the population $(n=8)$ with the lower $\delta^{15} \mathrm{~N}_{\mathrm{PN}}$ values, between -3.2 and $-2.8 \%$, represents materials derived mainly from anthropogenic wastes. The mean $\delta^{15} \mathrm{~N}_{\mathrm{PN}}$ value of the population weighted by $\mathrm{PN}$ concentration is $-3.0 \%$; the population's weighted mean of $\delta^{13} \mathrm{C}_{\mathrm{POC}}$ value is $-23.5 \%$ and that of $\mathrm{C} / \mathrm{N}$ ratio is 8.2 . The inferred composition of the anthropogenic waste-derived organic matter is different from that of the sewage sludge samples collected from the Dihua Waste Water Treatment Plant (Table 3). It is suspected that the sewage sludge samples may not be representative. These samples displayed isotopic compositions between those of the bedrockderived sediments and soil suggesting that they may represent the recalcitrant fraction of the sewage. The contribution of the treated sewage sludge to the SPM in the estuary is probably not important, because of the setback of waste water treatment in the greater Taipei metropolis (Lo, 2004). 
The isotopic and elemental compositions of sewagederived organic matter from 9 other localities are listed for comparison (Table 3). The $\delta{ }^{13} \mathrm{C}$ value of the inferred anthropogenic end-member falls well within the range of previously reported values $(-26.7$ to $-16.5 \%)$, whereas its $\delta^{15} \mathrm{~N}$ value is lower than all the rest, but not much lower than some values $(-1.1-1.1 \%$ ) reported for sewage sludge from the east coast of the USA (Table 3 ).

\subsubsection{Autochthonous POM}

In the Schelde Estuary, algal production is an important source of POM in the river-estuary-coastal zone system (Middelburg and Nieuwenhuize, 1998). Similar process may also happen in the Danshuei Estuary, but the autochthonous POM may not be as significant due to the short residence time of the estuarine water of 1-2 d (Wang et al., 2004). The residence time of the river water above the tidal reach is probably equally short or even shorter (M.-S. Li, personal communication), because the main channel of the Danshuei River is very steep, with a mean slope of $1 / 45$. Consequently, the algal growth before river water enters the estuary is probably very limited. We may assume that most autochthonous POM is produced either in the estuary or in the coastal zone outside the estuary.

The POM collected in the continental shelf north of Taiwan showed considerable variation in carbon and nitrogen isotopic compositions with $\delta^{13} \mathrm{C}_{\mathrm{POC}}$ ranging from -24.4 to $-19.1 \%$ and $\delta{ }^{15} \mathrm{~N}_{\mathrm{PN}}$ values ranging from -2.3 to $4.9 \%$ (Chen et al., 2001), but the two samples with the highest Chl-a concentrations $\left(\geq 1 \mathrm{mg} \mathrm{m}^{-3}\right)$ showed rather consistent $\delta^{13} \mathrm{C}_{\mathrm{POC}}$ values of -21.2 to $-19.1 \%$ and $\delta{ }^{15} \mathrm{~N}_{\mathrm{PN}}$ values of 3.5-4.9\%. The mean $\delta^{13} \mathrm{C}$ value is very close to that of phytoplankton $(-20.1 \pm 1.8 \%$ ) observed in the Otsuchi Bay, Japan (Wada et al, 1984). The mean $\delta{ }^{15} \mathrm{~N}_{\mathrm{PN}}$ value is very close to that of nitrate, $4.7 \pm$ $0.6 \%$, in the Kuroshio upwelling water, which is the main nutrient source to the East China Sea (Liu et al., 1996; Gong et al., 1996). Hence, the mean isotope compositions may represent the marine end-member (Table 3).

Following the approach of Cifuentes et al. (1988), we use the Chl-a to POC ratio to distinguish samples dominated by freshly produced POM from the rest (Fig. 7). The freshly produced POM has $\mathrm{Chl}-\mathrm{a} / \mathrm{POC}$ ratio greater than $1 / 200$ or $5 \mu \mathrm{g} \mathrm{mg}^{-1}$. It is noted that all freshly produced POM should be autochthonous, but autochthonous POM may not all be fresh. It is shown later that some autochthonous POM have slightly lower Chl-a/POC ratio.

All samples with the ratio greater than $5 \mu \mathrm{g} \mathrm{mg}^{-1}$ had the highest $\delta^{13} \mathrm{C}_{\mathrm{POC}}$ values (as indicated in Section 3.1), implying the ${ }^{13} \mathrm{C}$-enriched POC was newly produced. Most $\delta{ }^{15} \mathrm{~N}$ values of the freshly produced POM fell above the background level. This suggests that the main nitrogen source of the phytoplankton growing in the estuary was a nitrogen source more enriched in ${ }^{15} \mathrm{~N}$ than the ammonia regenerated from anthropogenic wastes.
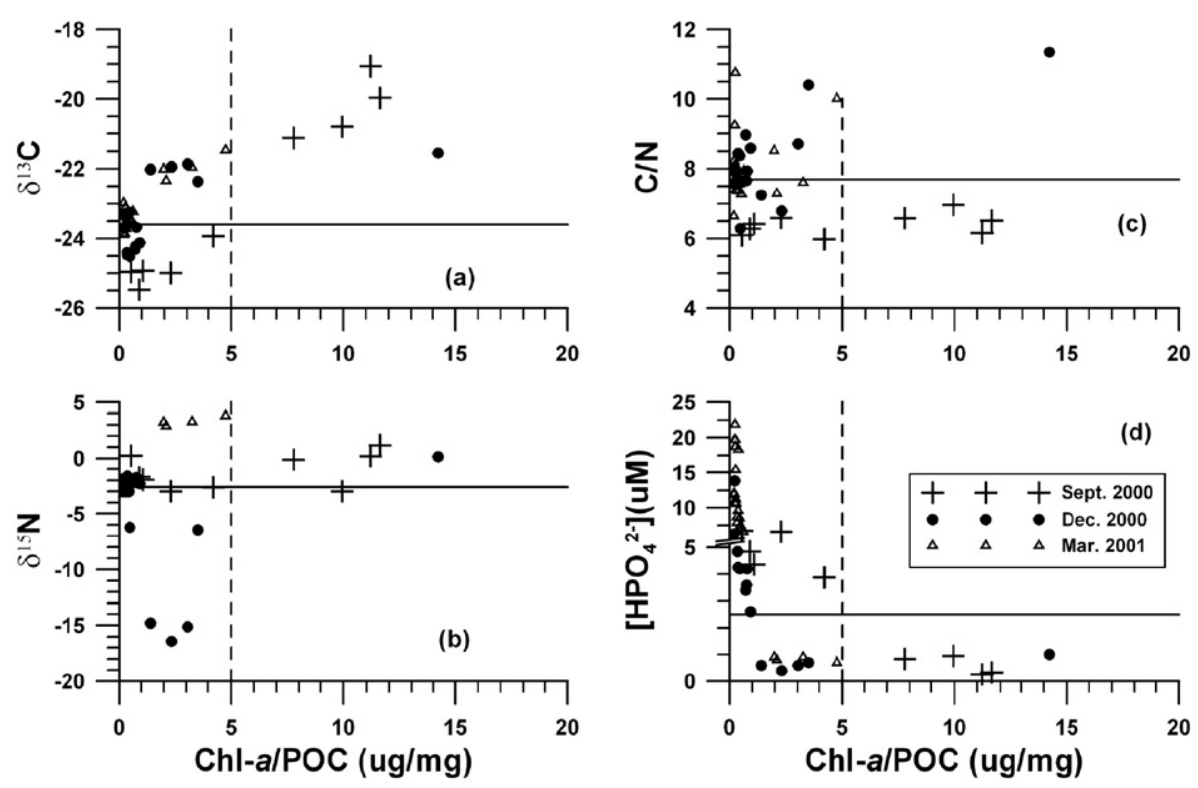

Fig. 7. Properties of estuarine water samples vs. the Chl-a/POC ratio. Samples with the Chl-a/POC ratio above $5 \mu \mathrm{g} \mathrm{mg}^{-1}$ are considered as containing high fraction of freshly produced POM. (a) $\delta^{13} \mathrm{C}$ value. (b) $\delta^{15} \mathrm{~N}$ value, (c) $\mathrm{C} / \mathrm{N}$ ratio and (d) phosphate concentration. The horizontal line represents the weighted mean in the first three panels; for panel $(\mathrm{d})$, it represents the phosphate concentration $(2.5 \mu \mathrm{M})$ distinguishing the highly polluted waters from the rest (see text). 
This is to be discussed later. By contrast, the $\mathrm{C} / \mathrm{N}$ ratio $(6.0-10.8)$ of the freshly produced POM covers almost the entire range of observed $\mathrm{C} / \mathrm{N}$ ratios (Table 2). It is interesting to note that those data points from September 2000 all fell on the lowest level of $\mathrm{C} / \mathrm{N}$ ratio between 6.0 and 7.0, whereas the two data points from the other two sampling occasions were the highest, suggesting different classes of phytoplankton with different $\mathrm{C} / \mathrm{N}$ ratios thriving under different estuarine conditions.

\subsubsection{Factors affecting the isotopic composition of} autochthonous POC

It is noteworthy that both the highest $(-19.0 \%)$ and the lowest $(-25.5 \%) \quad \delta^{13} \mathrm{C}_{\mathrm{POC}}$ value occurred in September 2000. The highest value occurred in waters with highest salinity, whereas the lowest value occurred in the mid salinity of about 12 (Fig. 2b). This trend is worth discussion.

The carbon isotopic composition of phytoplankton produced POM is controlled (Rau et al., 1996; Barth et al., 1998) by that of the starting material and by isotope effect during photosynthesis. The isotope effect has been found to be controlled mainly by the isotope fractionation during carbon fixation and the diffusive process from the ambient aqueous medium, which is mainly controlled by the ambient concentration of dissolved $\mathrm{CO}_{2}$ (Rau et al., 1996). The higher $\left[\mathrm{CO}_{2}\right]_{\mathrm{aq}}$ is, the stronger the fractionation gets. The overall isotope fractionation between the phytoplankton produced POM and DIC ranges from $-18 \%$ to $-35 \%$ in aquatic environments (Hofmann et al., 2000, Lehmann et al., 2004) with most values around $-20 \%$. In other words, the phytoplankton POC is isotopically lighter than

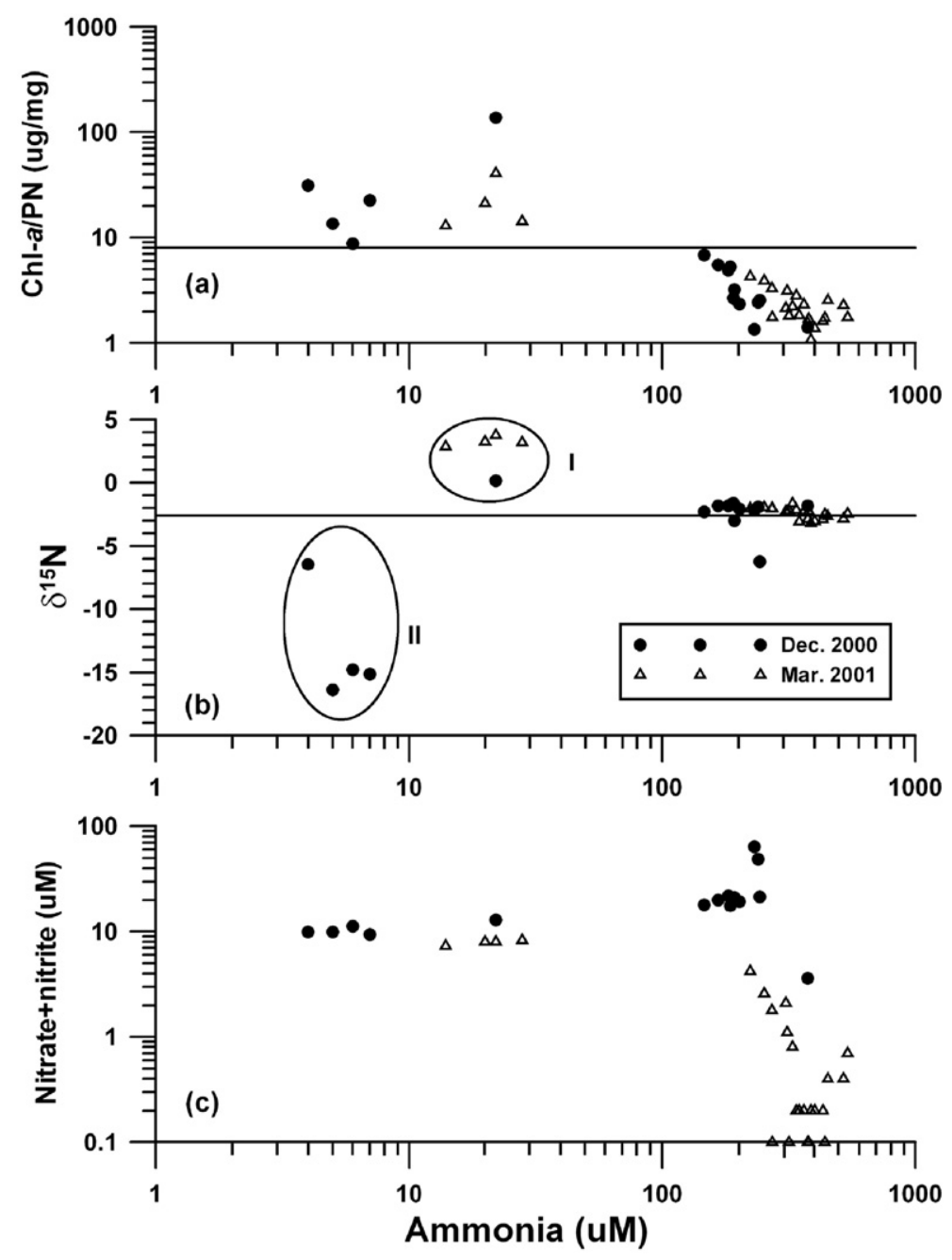

Fig. 8. Properties of estuarine water samples vs. the ammonium concentration. (a) Chl-a/PN ratio., (b) $\delta^{15} \mathrm{~N}$ value. (c) concentration of nitrate plus nitrite. The sudden drop of $\delta^{15} \mathrm{~N}$ values for ammonia concentration less than $7.5 \mu \mathrm{M}$ suggests switch of nitrogen uptake from ammonia to nitrate or nitrite by phytoplankton. 
the ambient DIC by about $20 \%$ on average with variability depending on local conditions.

Sheu et al. (1996) found DIC concentrations between 1900 and $2050 \mu \mathrm{Mol} \mathrm{kg}^{-1}$ with $\delta^{13} \mathrm{C}$ values around $+0.25 \%$ in the surface water near Taiwan. The POM produced from such ambient DIC would have a $\delta^{13} \mathrm{C}$ value around $-19.7 \%$, which is close to the upper limit of the $\delta{ }^{13} \mathrm{C}$ values observed at the highest salinity in the Danshuei Estuary (Fig. 2b). The much lower $\delta^{13} \mathrm{C}_{\mathrm{POC}}$ values found at lower salinity may be attributed to two major factors: the high concentration and the low $\delta^{13} \mathrm{C}$ value of ambient dissolved $\mathrm{CO}_{2}$. The water with lower salinity had higher concentrations of ammonia and phosphate (Fig. 3b, c), and probably also higher DIC concentration due to mineralization of anthropogenic wastes. Sheu et al. (1996) reported $\delta{ }^{13} \mathrm{C}$ values of DIC in Taiwanese river waters mostly between -7 and $-5 \%$, which were lower than the surface seawater due to decomposition of isotopically light POC. It is likely that the DIC in the Danshuei Estuary had similarly low $\delta^{13} \mathrm{C}$ values.

The most negative $\delta^{13} \mathrm{C}_{\mathrm{POC}}$ value observed was $-25.5 \%$, which occurred in the estuarine water with $\mathrm{Chl}-\mathrm{a} / \mathrm{POC}$ ratio of $1 \mu \mathrm{g} \mathrm{mg}^{-1}$. The bulk POC is a mixture of the autochthonous POC and the background material, which may have a $\delta^{13} \mathrm{C}$ value close to the mean of allochthonous POC, $-23.7 \%$.. Derivation of this value is to be shown later. If the phytoplankton produced POM has a Chl-a/POC ratio of $5 \mu \mathrm{g} \mathrm{mg}^{-1}$, a simple mixing relation suggests that this sample contains only $20 \%$ of phytoplankton produced POM. Using the same relation we calculated the $\delta{ }^{13} \mathrm{C}$ value of phytoplankton produced POC to be $-32.7 \%$. Similarly low $\delta{ }^{13} \mathrm{C}$ value $(-31.5 \%$ ) was observed in the nearshore environment of the St. Lawrence River, where the $\delta^{13} \mathrm{C}$ value of DIC reached as low as $-13 \%$ (Barth et al., 1998).

In contrast to the rather wide range of $\delta{ }^{13} C_{P O C}$ values occurring in September 2000, the ranges observed on the other two occasions were considerably narrower, with limited expansion away from the background level (Figs. 2b and 7a). The narrower ranges seemed to indicate the stronger background signal contributed by soils, bed-rock derived sediments and wastes, which all have similar $\delta^{13} \mathrm{C}$ values (Table 3 ). However, this could also result from smaller isotope effect during photosynthesis, probably manifested by a different dominant class of phytoplankton, as suggested by the much higher $\mathrm{C} / \mathrm{N}$ ratio (Fig. 7c). Further study is needed to verify this notion.

\subsubsection{Nitrogen uptake and isotope fractionation}

The isotopic compositions of PN observed in the Danshuei Estuary cover a wide range of $\delta^{15} \mathrm{~N}$ values from -16.4 to $+3.8 \%$. As mentioned in Section 4.3.2, most freshly produced POM had $\delta^{15} \mathrm{~N}$ values higher than the background level. This enrichment of ${ }^{15} \mathrm{~N}$ in the phytoplankton needs an explanation. On the other hand, the very negative lower limit is much lower than those observed in other estuaries (Table 2). A similarly low $\delta^{15} \mathrm{~N}_{\mathrm{PN}}$ value, down to $-5 \%$, was observed in the outflow region of the Lanyang Hsi in the northeastern Taiwan (Hsueh, 1991). Therefore, the unusually low $\delta^{15} \mathrm{~N}_{\mathrm{PN}}$ values deserve attention.

The occurrences of the unusual $\delta^{15} \mathrm{~N}_{\mathrm{PN}}$ values, either higher or lower than the background level, appear to be controlled by nitrogen uptake. Since phytoplankton has a preference for ammonium to nitrate during nitrogen uptake (McCarthy et al., 1977), the nitrogenous species used by phytoplankton was in turn controlled by the ammonium concentration. Nitrogen uptake associated with the production of autochthonous POM is indicated by the Chl-a/PN ratio (Fig. 8a). Nine samples with elevated $\mathrm{Chl}-\mathrm{a} / \mathrm{PN}$ ratio $\left(>8 \mu \mathrm{g} \mathrm{mg}{ }^{-1}\right)$ occurred at ammonium concentrations below $30 \mu \mathrm{M}$. These samples all had $\delta{ }^{15} \mathrm{~N}_{\mathrm{PN}}$ values distinctive from those of the highly polluted samples with very high concentration of ammonium.

The first group of samples that had ammonium concentrations between 10 and $30 \mu \mathrm{M}$ displayed $\delta^{15} \mathrm{~N}_{\mathrm{PN}}$ values higher than the background level around $-2.6 \%$ (Fig. 8b). The second group that had the lowest $\delta^{15} \mathrm{~N}_{\mathrm{PN}}$ values occurred at the lowest ammonium concentrations, which were all below $8 \mu \mathrm{M}$. By contrast, the concentrations of nitrate plus nitrite of these samples all stayed at a fairly constant level around $10 \mu \mathrm{M}$, which was probably sustained by nitrification as mentioned in Section 3.1. It is noted that the second group of samples had Chl-a/POC ratio lower than $5 \mu \mathrm{g} \mathrm{mg}^{-1}$, which does not qualify them as containing a high fraction of freshly produced POM. However, there are good reasons to believe that they contained mostly autochthonous POM. Their Chl-a/POC ratios, though lower than the critical level, were higher than $2 / 3$ of all samples. They had the lowest levels of ammonium and highest salinities (Fig. 3b), suggesting that they might contain the highest proportions of marine materials.

The ${ }^{15} \mathrm{~N}$ enrichment in the first group of samples (Fig. 8a) could be due to uptake of isotopically heavy ammonia, which was probably the residual remaining from nitrification, as observed in the Schelde Estuary (Middelburg and Nieuwenhuize, 2001). The sudden drop of the $\delta^{15} \mathrm{~N}_{\mathrm{PN}}$ values of the second group of samples suggests a switch of nitrogen uptake from predominantly ammonia to predominantly nitrate or nitrite during phytoplankton growth. The threshold 
concentration of ammonium for inhibition of nitrate uptake by phytoplankton is usually in the range of $0.3-$ $1 \mu \mathrm{M}$ (Eppley et al., 1969; Wheeler and Kokkinakis, 1990), but the threshold may be elevated by a factor of 10 or more for algae in ammonia replete environments, such as oyster ponds (Maestrini et al., 1986). Culture experiments demonstrated that the threshold concentrations varied between 21 and $44 \mu \mathrm{M}$, depending on algal species (Maestrini et al., 1986), where ammonium remained high persistently. Most interestingly, the same experiments showed that the nitrate uptake increased rapidly to maximum rates, when the ambient ammonium concentration dropped to $7.5 \mu \mathrm{M}$ or lower, which agrees very well with our observations.

The very negative $\delta^{15} \mathrm{~N}$ values of the autochthonous $\mathrm{PN}$ in the second group of samples may be attributed to two factors. The isotopic composition of the products of nitrification, namely, nitrate and nitrite, could be rather low due to preferential oxidation of isotopically light ammonia (Miyake and Wada, 1971). The uptake of nitrate again favors isotopically light nitrate (Wada and Hattori, 1978; Pennock et al., 1996). The superimposed effects must have made the phytoplankton produced PON very depleted in ${ }^{15} \mathrm{~N}$.

\subsection{Biogeochemical considerations}

The similarities in carbon isotopic compositions of POC in estuaries suggest that they are controlled by similar biogeochemical processes. By contrast, the nitrogen isotopic compositions of $\mathrm{PN}$ in estuaries exhibit different ranges in different types of estuaries, suggesting different biogeochemical pathways of nitrogen cycle must be operating in different estuaries. An important manifestation of the different biogeochemical pathways is the presence or absence of isotopically heavy PN in the estuary. The high enrichment of ${ }^{15} \mathrm{~N}$ in the Delaware Bay and the Schelde Estuary (Table 2) is attributed to preferential removal of ${ }^{14} \mathrm{~N}$ in the uptake of ammonia by phytoplankton and other processes, such as nitrification and denitrification (Owens, 1985; Cifuentes et al., 1988; Middelburg and Nieuwenhuize, 1998). Enrichment of ${ }^{15} \mathrm{~N}$ in PN was also observed in the Danshuei Estuary near the river mouth, but the magnitude was very small (Fig. 8b), probably due to the very short residence time of the estuarine water (Wang et al., 2004) and the rather low primary production, $128 \mathrm{mg}$ $\mathrm{m}^{-2} \mathrm{~d}^{-1}$ (Wu and Chou, 2003). By comparison, the residence time of the Delaware Estuary or the Schelde Estuary is several months long (Cifuentes et al., 1988, Middelburg and Nieuwenhuize, 1998); the average primary production of the Delaware Bay is $840 \mathrm{mg}$ $\mathrm{m}^{-2} \mathrm{~d}^{-1}$ (Pennock and Sharp, 1986). The Tokachi River (Usui et al., 2006) and the Forth Estuary (Graham et al., 2001), where the ${ }^{15} \mathrm{~N}$ enrichment was also quite small (Table 2), may serve as test cases for this residence time hypothesis.

The isotopically very light PN observed near the river mouth of the Danshuei Estuary has not been observed in other estuaries. The very low $\delta^{15} \mathrm{~N}_{\mathrm{PN}}$ values, which were attributed to nitrate uptake as discussed above, may occur only in the early stage of nitrification. With increasing degree of reaction, the isotopic composition of the product should become more enriched in the heavier isotope for reactions favoring the light isotopes (Hoefs, 1997). Middelburg and Nieuwenhuize (2001) reported that nitrate is a dominant species in most estuarine waters in three temperate estuaries in Europe. It is also the case in the Delaware Bay (Cifuentes et al., 1988). By contrast, ammonia is generally the dominant species in the Danshuei Estuary. Here nitrification and nitrate uptake occurred only near the river mouth.

\subsection{Allochthonous contributions to estuarine POM}

It has been shown that the autochthonous POM could be quite variable in isotopic and elemental compositions. By comparison, each of the allochthonous POM sources, namely, anthropogenic wastes, soils and bedrock derived sediments, is probably more uniform in composition. Materials from the same origin may be better homogenized because of the much longer life time, which allows them to be homogenized. Therefore, for samples without significant contribution of autochthonous POM, it is feasible to estimate contributions of different types of allochthonous POM in the estuary. We used two criteria to decide the allochthonous POM dominated samples for the non-typhoon conditions, namely, the Chl-a/POC ratio less than $2 \mu \mathrm{g} \mathrm{mg}^{-1}$ and the phosphate concentration greater than $2.5 \mu \mathrm{M}$. In fact, all samples but two that met the second criterion also met the first criterion (Fig. 7d). Out of 49 samples there were 36 that met both criteria. It is also assumed that most samples collected under typhoon conditions were allochthonuos POM-dominated.

The compositions of the three end-members are chosen as within 1 standard deviation from the measured mean (Table 3 ) such that all but one typhoon samples fall within or near the compositional triangle of mixtures (Fig. 5). Among non-typhoon samples, two thirds also fall within or near the triangle. The notable exceptions mostly are samples obtained in 
Table 4

Contributions of different sources to the POC and PN in the Danshuei Estuary calculated from the three end-member mixing model

\begin{tabular}{|c|c|c|c|c|c|c|c|}
\hline \multirow[b]{3}{*}{ Conditions } & & \multicolumn{6}{|c|}{ End-members } \\
\hline & & \multicolumn{2}{|c|}{ Nitrogen-based } & \multirow{2}{*}{$\frac{\text { Fractions }}{\text { Sediments }}$} & \multicolumn{2}{|c|}{ Carbon-based } & \multirow{2}{*}{$\frac{\text { Fractions }}{\text { Sediments }}$} \\
\hline & & Wastes & Soils & & Wastes & Soils & \\
\hline \multirow[t]{2}{*}{ Non-typhoon } & Range & $74-95 \%$ & $0-23 \%$ & $0-24 \%$ & $62-91 \%$ & $0-36 \%$ & $0-20 \%$ \\
\hline & Mean & $87 \%$ & $7 \%$ & $6 \%$ & $83 \%$ & $12 \%$ & $5 \%$ \\
\hline \multirow[t]{2}{*}{ Typhoon } & Range & $0-96 \%$ & $0-59 \%$ & $4-81 \%$ & $0-96 \%$ & $0-77 \%$ & $4-70 \%$ \\
\hline & Mean & $12 \%$ & $44 \%$ & $45 \%$ & $9 \%$ & $63 \%$ & $28 \%$ \\
\hline
\end{tabular}

The calculation was conducted for samples without significant autochthonous POM. (See text.) The mean values are concentration weighted averages.

September 2000, when the phytoplankton flourished after the typhoon season. The contributions of the three major types of POM in each sample were derived from the $\delta{ }^{15} \mathrm{~N}_{\mathrm{PN}}$ value and the $\mathrm{C} / \mathrm{N}$ ratio. The nitrogen-based fraction of each type may be calculated as follows:

$$
\begin{aligned}
f_{w}= & {\left[R\left(r-r_{\text {sed }}\right)-\left(d-d_{\text {sed }}\right)\right] / } \\
& {\left[r\left(r_{\text {soil }}-r_{\text {sed }}\right)-\left(d_{\text {soil }}-d_{\text {sed }}\right)\right], } \\
f_{\text {soil }}= & \left(d-d_{\text {sed }}\right) /\left(d_{w}-d_{\text {sed }}\right) \\
& -f_{w}\left(d_{\text {soil }}-d_{\text {sed }}\right) /\left(d_{w}-d_{\text {sed }}\right)
\end{aligned}
$$

$f_{\text {sed }}=1-f_{w}-f_{\text {soil }}$

where $f$ represent the fraction of each end member, $r$ represents the $\mathrm{C} / \mathrm{N}$ ratio, $d$ represents the $\delta^{15} \mathrm{~N}_{\mathrm{PN}}$ value, and the subscripts, $w$ and sed, stand for wastes and bedrock-derived sediments, respectively. The parameter, $R$, is defined as follows:

$R=\left(d_{w}-d_{\text {sed }}\right) /\left(r_{w}-r_{\text {sed }}\right)$.

For carbon-based fraction (g), the following relationship may be used for the conversion:

$g_{i}=f_{i} \cdot r i / \sum_{i}\left(f_{i} \cdot r_{i}\right)$,

where $i$ denotes each of the three end-members. Derivations of these relationships are based on mass balance equations Liu and Kao, 2007.

The calculation was carried out for the 36 potentially allochthonous POM dominated samples from the nontyphoon periods and 15 from the typhoon period. However, those samples that fell out of the triangle defined by the three end-members in Fig. 5 could not be properly calculated with the previously shown relationships because negative fractions were obtained for those samples. Such conditions could be caused by three possible reasons: (1) some samples comprise significant fractions of end-members other than the three assumed here; (2) the isotopic and elemental compositions of the end-members are not as uniform as we assumed; and (3) uncertainties of the measurements. For those samples negative fractions were obtained, we re-did the calculation using the two end-members with nonnegative fractions by reducing the fractions proportionally to make the sum $100 \%$. If the differences were within $1 / 10$ of the original results, we retained the new results; otherwise, we rejected the samples. We did so assuming that, for the latter two possibilities, the errors of the calculated fractions should be relatively small. Only 8 samples out of 51 were rejected because of their significant deviation from the compositions defined by the three allochthonous end-members.

The calculated results are summarized in Table 4 . Under non-typhoon conditions, the anthropogenic waste was the dominant end-member, contributing $62-91 \%$ to the POC in the Danshuei Estuary. The concentration weighted mean fraction of it was $83 \%$. The soil and the bedrock-derived sediment contributed up to $36 \%$ and $20 \%$, respectively, but their weighted mean fractions were merely $12 \%$ and $5 \%$, respectively. Under typhoon conditions, soil was the dominant source of POC comprising up to $77 \%$. The weighted mean fraction was $63 \%$. The contribution of the bedrock-derived sediment was comparable, ranging from $4 \%$ to $70 \%$ with a weighted mean of $28 \%$. The mean contribution of the anthropogenic waste was only $9 \%$. The choice of end-member compositions may change the results of the calculation, but the changes are limited. A shift of the $\delta^{15} \mathrm{~N}_{\mathrm{PN}}$ value or the $\mathrm{C} / \mathrm{N}$ ratio of any end-member by 0.5 unit may cause the calculated mean fractions to change by no more than 1/15 of the original values Liu and Kao, 2007.

The presence of relatively fresh or bedrock-derived organic carbon can be indicated by the ${ }^{14} \mathrm{C}$ contents (Kao and Liu, 1996), which may be estimated from the 
organic carbon percentage of the SPM (Komada et al., 2004). The non-typhoon SPM displayed organic carbon contents ranging from $0.64 \%$ to $28.4 \%$ with a weighted mean of $14.8 \%$. We calculated the $\triangle^{14} \mathrm{C}$ values of the samples using the relationship established by Komada et al. (2004):

$$
\Delta^{14} \mathrm{C}=-517 / \mathrm{OC} \%+47
$$

About $1 / 3$ of the calculated $\triangle{ }^{14} \mathrm{C}$ values were positive, suggesting these samples contained significant amount of modern organic carbon. The weighted mean of $\triangle^{14} \mathrm{C}$ value of all samples was $-27 \%$. This supports our findings that the dominant component of POM under non-typhoon conditions was derived from anthropogenic wastes. By comparison, under typhoon conditions, the organic carbon contents in SPM ranged from $0.67 \%$ to $7.7 \%$ with a weighted mean of $1.44 \%$. The weighted mean of $\triangle{ }^{14} \mathrm{C}$ value was $-471 \%$, supporting the findings of a significant contribution from bed-rock derived sediments.

\section{Conclusions}

The major sources of organic matter in the suspended particulate matter in the estuary include anthropogenic wastes, soils, bedrock-derived sediments and phytoplankton produced POM. The majority (29 out of 49) of non-typhoon samples and all $(n=15)$ but one typhoon samples were dominated by allochthonous POM. Using a three end-member mixing model, we found the average contributions of different sources to the allochthonous POC in the estuary: 83\% from anthropogenic waste, $12 \%$ from soils and $5 \%$ from bedrockderived sediments for non-typhoon conditions. For the typhoon condition, the contributions were $9 \%, 63 \%$ and $28 \%$, respectively.

Only $1 / 7$ of samples from non-typhoon periods, mostly from September 2000 shortly after the typhoon season, showed dominance of phytoplankton produced POM. The autochthonous POM showed the most varied carbon and nitrogen isotopic compositions, attributable to the highly variable biogeochemical conditions. The isotopically heavy POC represented the marine end-member produced in the coastal zone, whereas the isotopically light POC represented the estuarine condition, probably with elevated concentration of dissolved inorganic carbon derived from the isotopically light organic matter.

The lack of isotopically heavy nitrogen in the Danshuei Estuary was attributed to the rather low $\delta^{15} \mathrm{~N}$ value $(-3 \%)$ of the main nitrogen source in the estuary, namely, anthropogenic wastes. Moreover, the short residence time of the estuarine water and the low primary production (Wu and Chou, 2003), limited ammonia uptake, a major pathway for enriching ${ }^{15} \mathrm{~N}$ in estuaries (Owen, 1985). The very low $\delta^{15} \mathrm{~N}_{\mathrm{PN}}$ values $(-16.4$ to $-6.4 \%$ ) occurred in waters with ammonia concentrations lower than $7.5 \mu \mathrm{M}$ and relatively high $\mathrm{Chl}-\mathrm{a} / \mathrm{PN}$ ratios, suggesting a switch of the nitrogen source from ammonia to nitrate near the river mouth, where nitrification took place.

Further studies are needed to verify the hypotheses derived from the observations here. Most critical is to identify the nature and origin of anthropogenic wastes. It is also important to investigate the isotopic compositions of dissolved inorganic carbon and different species of dissolved inorganic nitrogen, which are the carbon and nitrogen sources of the autochthonous organic matter. Study is also warranted to examine precursors of nitrogenous materials in the estuary, such as dissolved organic nitrogen, and their transformation. The contrasting $\mathrm{C} / \mathrm{N}$ ratios and isotopic compositions of autochthonous POM may be attributed to different classes of phytoplankton, which need to be examined under different conditions in the estuary.

\section{Acknowledgments}

This manuscript has benefited greatly from thorough and constructive comments provided by Dr. J. Barth and an anonymous reviewer and useful input from Dr. Ming-Hsu Li. The main support of this study came from Academia Sinica and the National Science Council of Taiwan. This is NCU-IHS contribution no. 58 .

\section{References}

Andrews JE, Greenaway AM, Dennis PF. Combined carbon-isotope and $\mathrm{C} / \mathrm{N}$ ratios as indicators of source and fate of organic-matter in a poorly flushed, tropical estuary — Hunts Bay, Kingston Harbor, Jamaica. Estuar Coast Shelf Sci 1998;46: 743-56.

Barth JAC, Veizer J, Mayer B. Origin of particulate organic-carbon in the upper St.-Lawrence-isotopic constraints. Earth Planet Sci Lett 1998;162: 111-21.

Chang FY, Kao S-J, Liu K-K. Analysis of organic and carbonate carbon in sediments (in Chinese, with English abstract). Acta Oceanogr Taiwanica 1991;27: 140-50.

Chen K-L, Kao S-J, Liu K-K. Fluxes and isotopic compositions of particulate organic carbon and nitrogen from the Tamshuei River during typhoon flood (in Chinese, with English abstract). Acta Oceanogr Taiwanica 2001;39: 219-32.

Cifuentes LA, Fogel ML, Sharp JH. Stable carbon and nitrogen isotope biogeochemistry in the Delaware Estuary. Limnol Oceanogr 1988;33: 1102-15.

Cole JJ, Peierls BL, Caraco NE, Pace ML. Nitrogen loading of rivers as a human-driven process. Springer Verlag; 1993 . p. 141-57. 
Eppley RW, Roger JN, McCarthy JJ. Half-saturation constants for uptake of nitrate and ammonium by marine phytoplankton. Limnol Oceanogr 1969;12: 196-206.

Gong GC, Liu KK, Pai SC. Prediction of nitrate concentration from 2 end-member mixing in the southern East-China-Sea. Cont Shelf Res 1995;15: 827.

Gong GC, Chen YLL, Liu KK. Chemical hydrography and chlorophyll-a distribution in the east-China-sea in summer - implications in nutrient dynamics. Cont Shelf Res 1996;16: 1561-90.

Graham MC, Eaves MA, Farmer JG, Dobson J, Fallick AE. A study of carbon and nitrogen stable-isotope and elemental ratios as potential indicators of source and fate of organic-matter in sediments of the Forth Estuary, Scotland. Estuar Coast Shelf Sci 2001;52: 375-80.

Ho CS. An introduction to the geology of Taiwan. Taipei, Taiwan, Republic of China: The Ministry of Economic Affairs; 1975. 153 pp.

Hoefs J. Stable isotope geochemistry. Berlin: Springer Verlag; 1997. 201 pp.

Hofmann M, Wolfgladrow DA, Takahashi T, Sutherland SC, Six KD, Maierreimer E. Stable carbon-isotope distribution of particulate organicmatter in the ocean - A model study. Mar Chem 2000;72: 131-50.

Hsueh C-R. Improvement of nitrogen isotopic analysis of nitrate in seawater and preliminary study of particulate organic nitrogen near the Lanyang Hsi River mouth [in Chinese]. National Taiwan University, M.S. Thesis, 1991, (96 pp).

Hunt CD, West DE, Peven CS. Deer Island effluent characterization and pilot treatment plant studies: June 1993-November 1994. MWRA Technical Report No 95-7 1995.

Jennerjahn TC, Ittekkot V, Kloper S, Adi S, Nugroho SP, Sudiana N, et al. Biogeochemistry of a tropical river affected by human activities in its catchment - Brantas River Estuary and coastal waters of Madura Strait, Java, Indonesia. Estuar Coast Shelf Sci 2004;60(3): 503-14.

Kao S-J, Liu K-K. Particulate organic-carbon export from a subtropical mountainous river (Lanyang-Hsi) in Taiwan. Limnol Oceanogr 1996;41: 1749-57.

Kao S-J, Liu K-K. Stable carbon and nitrogen isotope systematics in a human- disturbed watershed (Lanyang-Hsi) in Taiwan and the estimation of biogenic particulate organic-carbon and nitrogen fluxes. Glob Biogeochem Cycles 2000;14: 189-98.

Ko FC, Baker JE. Seasonal and annual loads of hydrophobic organic contaminants from the Susquehanna River basin to the Chesapeake Bay. Mar Pollut Bull 2004;48: 840-51.

Komada T, Druffel ERM. Trumbore SE. Oceanic export of relict carbon by small mountainous rivers. Geophys Res Lett 2004;31: L07504. doi:10.1029/2004GL019512.

Lehmann MF, Bernasconi SM, McKenzie JA, Barbieri A, Simona M, Veronesi $\mathrm{M}$. Seasonal variation of the $\mathrm{d}^{13} \mathrm{C}$ and $\mathrm{d}^{15} \mathrm{~N}$ of particulate and dissolved carbon and nitrogen in Lake Lugano: constraints on biogeochemical cycling in a eutrophic lake. Limnol Oceanogr 2004;49: 415-29.

Liu K-K, Kao S-J. A three end-member mixing model based on isotopic composition and elemental ratio. Terrest Atmospheric Oceanic Sci 2007; 18: (In review).

Liu K-K, Su MJ, Hsueh CR, Gong GC. The nitrogen isotopic composition of nitrate in the kuroshio water northeast of taiwan evidence for nitrogen-fixation as a source of isotopically light nitrate. Mar Chem 1996;54: 273-92.

Liu WC, Hsu MH, Kuo AY, Kuo JT. The influence of river discharge on salinity intrusion in the Tanshui estuary, Taiwan. J Coast Res 2001; 17: 544-52.

Lo S-L. Water pollution control of the Keelung River-design and engineering problems. Acta Oceanogr Taiwanica 2001;39: 161-73.
Maestrini SY, Collos Y, Leftley JW, Robert JM. Ammonium thresholds for simultaneous uptake of ammonium and nitrate by oyster-pond algae. J Exp Mar Biol Ecol 1986;102: 75-98.

McCarthy JJ, Taylor WR, Taft JL. Nitrogenous nutrition of the plankton in the Chesapeake Bay. 1. Nutrient availability and phytoplankton preferences. Limnol Oceanogr 1977;22: 996-1011.

McClelland JW, Valiela I. Changes in food-web structure under the influence of increased anthropogenic nitrogen inputs to estuaries. Mar Ecol Prog Ser 1998;168: 259-71.

Meyers EP. The concentration and isotopic composition of carbon in marine sediments affected by sewage discharge. California Institute of Technology, Ph.D. Dissertation, 1974, pp).

Middelburg JJ, Nieuwenhuize J. Carbon and nitrogen stable isotopes in suspended matter and sediments from the Schelde Estuary. Mar Chem 1998;60: 217-25.

Middelburg JJ, Nieuwenhuize J. Nitrogen isotope tracing of dissolved inorganic nitrogen behaviour in tidal estuaries. Estuar Coast Shelf Sci 2001;53: 385-91.

Miyake Y, Wada E. The isotope effect on the nitrogen in biochemical, oxidation-reduciton reactions. Rec Oceanogr Works Jpn 1971;11: 1-6.

Owens NJP. Variations in the natural abundance of ${ }^{15} \mathrm{~N}$ in estuarine suspended particulate matter - A specific indicator of biological processing. Estuar Coast Shelf Sci 1985;20: 505-10.

Pai SC, Yang CC, Riley JP. Effects of acidity and molybdate concentration on the kinetics of the formation of the phosphoantimonylmolybdenum blue complex. Anal Chim Acta 1990a;229: 115-20.

Pai SC, Yang CC, Riley JP. Formation kinetics of the pink azo dye in the determination of nitrite in natural-waters. Anal Chim Acta 1990b;232: 345-9.

Pai SC, Tsau YJ, Yang TI. pH and buffering capacity problems involved in the determination of ammonia in saline water using the indophenol blue spectrophotometric method. Anal Chim Acta 2001;434: 209-16.

Pennock JR, Sharp JH. Phytoplankton production in the Delaware Estuary — temporal and spatial variability. Mar Ecol Prog Ser 1986;34: 143-55.

Pennock JR, Velinsky DJ, Ludlam JM, Sharp JH, Fogel ML. Isotopic fractionation of ammonium and nitrate during uptake by Skeletonema costatum - Implications for $\mathrm{d}^{15} \mathrm{~N}$ dynamics under bloom conditions. Limnol Oceanogr 1996;41: 451-9.

Peters KE, Sweeney RE, Kaplan IR. Corelation of carbon and nitrogen isotope ratios in sedimentary organic matter. Limnol Oceanogr 1978;23: 598-604.

Rau GH, Kaplan IR, Mearns AJ, Sweeney RE, Young DR. Differences in animal $13 \mathrm{C},{ }^{15} \mathrm{~N}$ and $\mathrm{D}$ abundance between a polluted and an unpolluted coastal site - likely indicators of sewage uptake by a marine food web. Estuar Coast Shelf Sci 1981;13: 701-7.

Rau GH, Riebesell U, Wolfgladrow D. A model of photosynthetic ${ }^{13} \mathrm{C}$ fractionation by marine-phytoplankton based on diffusive molecular $\mathrm{CO}_{2}$ uptake. Mar Ecol Prog Ser 1996;133: 275-85.

Santschi PH, Lenhart JJ, Honeyman BD. Heterogeneous processes affecting trace contaminant distribution in estuaries - the role of natural organic-matter. Mar Chem 1997;58: 99-125.

Sheu DD, Lee WY, Wang CH, Wei CL, Chen CTA, Cherng C, et al. Depth distribution of $\mathrm{d}^{13} \mathrm{C}$ of dissolved $\mathrm{SCO}_{2}$ in seawater off eastern Taiwan - effects of the Kuroshio Current and its associated upwelling phenomenon. Cont Shelf Res 1996;16: 1609-19.

Sigleo AC, Macko SA. Carbon and nitrogen isotopes in suspended particles and colloids, Chesapeake and San Francisco estuaries, USA. Estuar Coast Shelf Sci 2002;54: 701-11.

Soil-Survey-Staff. Soil taxonomy: a basic system of soil classification for making and interpreting soil surveys. Agricultural handbook, vol. 436. Washington: USDA-NRCS, U.S. Gov. Print. Office; 1999. pp. 
Spies RB, Rice DW, Ireland R, Kruger H. Stable isotope ratios and contaminant concentrations in a sewage-distorted food web. Mar Ecol Prog Ser 1989;54: 157-70.

Strickland JDH, Parsons TR. A practical handbook of seawater analysis. Ottawa, Canada: Fisheries Research Board of Canada; 1972. $310 \mathrm{pp}$.

Sun YC, Peng CK. Characterization of the nutrients and toxic metals pollution in Da-Ham Stream. Acta Oceanogr Taiwanica 2001;39: 105-19.

Sweeney RE, Kalil EK, Kaplan IR. Characterization of domestic and industrial sewage in Southern-California coastal sediments using nitrogen, carbon, sulfur and uranium tracers. Mar Environ Res 1980;3: 225-43.

Thornton SF, McManus J. Application of organic-carbon and nitrogen stable-isotope and $\mathrm{C} / \mathrm{N}$ ratios as source indicators of organicmatter provenance in estuarine systems - evidence from the Tay Estuary, Scotland. Estuar Coast Shelf Sci 1994;38: 219-33.

Tucker J, Sheats N, Giblin AE, Hopkinson CS, Montoya JP. Using stable isotopes to trace sewage-derived material through Boston Harbor and Massachusetts Bay. Mar Environ Res 1999;48: 353-75.

Uncles RJ, Bloomer NJ, Frickers PE, Griffiths ML, Harris C, et al. Seasonal variability of salinity, temperature, turbidity and suspended chlorophyll in the Tweed Estuary. Sci Total Environ 2000;251(252): 115-24.

Usui T, Nagao S, Yamamoto M, Suzuki K, Kudo I, Montani S, et al. Distribution and sources of organic matter in surficial sediments on the shelf and slope off Tokachi, western North Pacific, inferred from $\mathrm{C}$ and N stable isotopes and C/N ratios. Mar Chem 2006;98: 241-59. van Dover CL, Grassle JF, Fry B, Garritt RH, Starczak VR. Stable isotope evidence for entry of sewage-derived organic material into a deep-sea food web. Nature 1992;360: 153-6.

Wada E, Hattori A. Nitrogen isotope effects in the assimilation of inorganic nitrogenous compounds by marine diatoms. Geomicrobiol J 1978;1: 85-101.

Wada E, Imaizumi R, Karasawa K, Minagawa M, Mizutani H, Tsuji T. Biogeochemical studies on the transport of organic-matter along the Otsuchi River watershed, Japan. Estuar Coast Shelf Sci 1987;25: 321-36.

Wada E, Mizutani H, Karasawa K, Kabaya Y, Minagawa M, Yonemoto S, et al. Carbon and nitogen isotopic composiiton as tracers of transport of organic matter along the Otsuchi watershed. Geochemistry 1984;18: 89-98.

Wang CF, Hsu MH, Kuo AY. Residence time of the Danshuei River estuary, Taiwan. Estuar Coast Shelf Sci 2004;60: 381-93.

Wedeking KW, Hayes JM, Matzigkeit U. Procedure of organic geochemical analysis. Princeton, N. J.: Princeton University Press; 1983 . p. 428-41.

Wheeler PA, Kokkinakis SA. Ammonium recycling limits nitrate use in the oceanic sub-arctic Pacific. Limnol Oceanogr 1990;35: 1267-78.

Wen L-S, Jiann K-T, Liu K-K. Seasonal variation and flux of dissolved nutrients in the Danshuei Estuary, Taiwan: A hypoxic subtropical mountainous river. Estuar Coast Shelf Sci 2007; (In revision).

Wu JT, Chou TL. Silicate as the limiting nutrient for phytoplankton in a subtropical eutrophic estuary of Taiwan. Estuar Coast Shelf Sci 2003;58: 155-62. 